\title{
Characterization of Artisanal Spontaneous Sourdough Wheat Bread from Central Greece: Evaluation of Physico-Chemical, Microbiological, and Sensory Properties in Relation to Conventional Yeast Leavened Wheat Bread
}

\author{
Pavlina Katsi ${ }^{1}$, Ioanna S. Kosma ${ }^{1}$, Sofia Michailidou ${ }^{2}$, Anagnostis Argiriou 2,3 (D), Anastasia V. Badeka ${ }^{1, *}$ \\ and Michael G. Kontominas ${ }^{1, *}$
}

check for updates

Citation: Katsi, P.; Kosma, I.S.;

Michailidou, S.; Argiriou, A.; Badeka,

A.V.; Kontominas, M.G.

Characterization of Artisanal Spontaneous Sourdough Wheat Bread from Central Greece:

Evaluation of Physico-Chemical,

Microbiological, and Sensory

Properties in Relation to

Conventional Yeast Leavened Wheat Bread. Foods 2021, 10, 635. https:// doi.org/10.3390/foods10030635

Academic Editors: Marina Carcea and Mike Sissons

Received: 27 January 2021

Accepted: 12 March 2021

Published: 17 March 2021

Publisher's Note: MDPI stays neutral with regard to jurisdictional claims in published maps and institutional affiliations.

Copyright: (c) 2021 by the authors. Licensee MDPI, Basel, Switzerland. This article is an open access article distributed under the terms and conditions of the Creative Commons Attribution (CC BY) license (https:// creativecommons.org/licenses/by/ $4.0 /)$.
1 Laboratory of Food Chemistry, Department of Chemistry, University of Ioannina, 45110 Ioannina, Greece; pavlina_katsi@hotmail.com (P.K.); i.kosma@uoi.gr (I.S.K.)

2 Centre for Research and Technology Hellas, Institute of Applied Biosciences, 6th km Charilaou-Thermis, 57001 Thessaloniki, Greece; sofia_micha28@certh.gr (S.M.); argiriou@certh.gr (A.A.)

3 Department of Food Science and Nutrition, University of the Aegean, 81400 Myrina, Lemnos, Greece

* Correspondence: abadeka@uoi.gr (A.V.B.); mkontomi@uoi.gr (M.G.K.)

Abstract: In the present study, both yeast leavened bread (YLB) and artisanal sourdough wheat bread (SDB) were prepared. The physico-chemical, microbiological, and sensory properties of breads were monitored as a function of storage time $\left(\mathrm{T}=25^{\circ} \mathrm{C}\right)$. As expected, the titratable acidity (TA) values of SDB were higher than those of YLB. The aroma profile of SDB was similar to that of YLB, including classes of compounds such as alcohols, aldehydes, ketones, esters, organic acids, terpenes, and sulfur compounds; however, the concentrations between the two were different. Aroma deterioration of bread during storage was partly related to the loss of several volatiles. Texture and sensory analysis showed that SDB was harder, less elastic, but richer in aroma and light sour taste than YLB. Mold growth was apparent when the population of yeasts/molds reached approximately $4 \log \mathrm{cfu} / \mathrm{g}$. This yeast/mold count was reached on days 4-5 for YLB and day $18+$ for SDB. A $16 S$ amplicon meta-barcoding analysis showed that the bacterial profile of SDB was dominated by a single genus, (Lactobacillus). Analysis of the eukaryotic load showed that the genus level, Saccharomyces and Alternaria were the most abundant genera, independently of the gene sequenced (18S or ITS). Based primarily on mold growth and texture data, which proved to be the most sensitive quality parameters, the shelf life was ca. $4-5$ days for YLB and 10 days for SDB.

Keywords: sourdough bread; yeast leavened bread; microbiological; physico-chemical; sensory analysis; shelf life

\section{Introduction}

Bread is probably the oldest "processed" food product. Carved images of bread furnaces have been recovered from Memphis ruins in Egypt as soon as 3000 B.C. Ancient Egyptians had over 50 different types of cakes, unleavened breads, and bread leavened with beer foam or sourdough [1]. Industrial wheat bread production started at the beginning of the 20th century after the introduction of baker's yeast as a superior leavening agent to sourdough and brewer's yeast. Ever since, the use of sourdough in bread production has been largely abandoned until very recently when consumer demand for the consumption of more natural bakery products with improved sensory properties and an extended shelf life, has revived the bakery industry's interest in using sourdough for breadmaking.

According to Ganzle and Gobbetti [2], the advantages of using sourdough in bread making include acidification, improvement of dough properties, improvement of texture, flavor, leavening capacity, delayed staling, and increased resistance to microbial spoilage. 
Furthermore, sourdough enhances the nutritional value of bread through increasing mineral bioavailability, reducing the phytate content, lowering the postprandial glucose level, and providing certain exopolysaccharides with prebiotic and anti-staling properties. All the above benefits have been attributed to the lactic acid bacteria and yeasts naturally present in sourdough [3]. The sourdough lactic acid bacteria (LAB) fermentation creates an optimum $\mathrm{pH}$ for the activity of the endogenous enzymes (amylases and proteases) and improves bread loaf volume, delays starch retrogradation and bread firming, inhibits ropiness by spore-forming bacteria, and enhances flavor [4].

Sourdough is a mixture of flour and water that is naturally fermented with a symbiotic culture of $\mathrm{LAB}$ and yeasts, native to the flour itself, in a multi-day procedure to reach a $\mathrm{pH}$ value below 4.5. The levels of $L A B$ in sourdough are $10^{8}-10^{9} \mathrm{cfu} / \mathrm{g}$, and the $\mathrm{LAB} /$ yeast ratio is generally 100:1 [5]. The most common LAB species found in sourdoughs are $L b$. acidophilus, $L b$. farciminis, $L b$. delbrueckii (obligate homofermentative), $L b$. casei, $L b$. plantarum, $L b$. rhamnosus (facultative heterofermentative), Lb. brevis, Lb. sanfransicencis, and $L b$. fermentum (obligate heterofermentative) [6]. The yeast flora of sourdough is more homogenous. Universal sourdough yeasts appear to be Saccharomyces cerevisiae, Candida milleri, or Candida humilis [7]. LAB are mainly responsible for dough acidification and the modification of dough properties, while yeasts are mainly responsible for the production of flavor compounds.

The quality of sourdough bread is influenced by the specific microbiota developed in sourdough (starter cultures of LAB and yeasts), flour type (wheat/rye, flour extraction rate), flour/water ratio (dough yield), and process parameters such as initial $\mathrm{pH}$, quantity of sourdough incorporated in dough, time and temperature of fermentation, etc. [5,8]. Specifically, temperature has a substantial impact on the dynamics of the microbial population and the metabolic activity of the microorganisms during fermentation. Homofermentative and facultative heterofermentative lactobacilli such as $\mathrm{Lb}$. fermentum and Lb. plantarum predominate when the fermentation temperature is above $30^{\circ} \mathrm{C}$. In contrast, heterofermentative lactobacilli such as $L b$. sanfranciscensis predominate when the temperature is lower than $30^{\circ} \mathrm{C}$ [8].

The shelf life of bread (time period within which bread retains its acceptable quality and safety characteristics) is substantially limited due to several deterioration factors, mostly microbial spoilage and texture firming [9]. Fungal growth is the most common path of bread spoilage owed to species of Penicillium and Aspergillus genera. Bread can also be spoiled from bacteria due to high levels of moisture (Bacillus subtilis, Bacillus cereus, Bacillus licheniformis). Likewise, ropy bread is caused by Bacillus subtilis, resulting in the deterioration of bread texture [10]. Microbial spoilage of bread is due to cross-contamination post baking, as all microbiota is destroyed during the baking process [11].

Physico-chemical changes in bread may occur involving texture and flavor deterioration, rendering it stale. Staling is characterized by crumb firming mainly due to the retrogradation of the starch polymers and interactions between starch and proteins, crust softening due to the transfer of moisture from the crumb to crust, and finally flavor changes. Such changes are responsible for the disposal of large quantities of bread (8-10\%), resulting in considerable economical losses [12-14].

Based on the above, the objectives of this study were (i) to characterize bread prepared using baker's yeast and artisanal sourdough on a qualitative and quantitative basis using physico-chemical, microbiological, and sensory analyses and (ii) to identify the specific microbiota dominating the sourdough bread.

\section{Materials and Methods}

\subsection{Artisanal Sourdough Preparation}

Two hundred grams of commercial wheat flour (85\% extraction rate) produced by steel roller grinding) at St. George Mills S.A. Ioannina, Greece, were mixed with $2 \mathrm{~g}$ of table salt $(0.6 \% w / w)$ and $200 \mathrm{~mL}$ of warm water $\left(30^{\circ} \mathrm{C}\right)$ in a bowl. The specific flour with a high extraction rate including a large part of the wheat bran is used to prepare sourdough in most 
parts of Greece. The ingredients were mixed using a sterilized spatula until a homogeneous thick batter was formed. Then, the bowl was covered with a hand towel and left overnight to rest at a temperature of $25 \pm 1{ }^{\circ} \mathrm{C}$. The following day, the dough was kneaded once more after adding $50 \mathrm{~g}$ flour and warm water $\left(30^{\circ} \mathrm{C}\right)$. This procedure was repeated for an additional 4 days, at which point the dough had matured/risen, forming a large number of holes in its mass and surface, which is a sign of vigorous fermentation activity, and giving off a sour and fresh odor. The mature dough, referred to as "sourdough", was placed in a mason-type jar and stored in the refrigerator while a part of it was used for bread making. The particular recipe for the preparation of the sourdough was that used in the area of Northern Nafpaktia, central Greece.

\subsection{Bread Preparation}

Two types of bread were prepared; bread leavened with baker's yeast (control, YLB) and sourdough bread (SDB). Control bread was prepared using $1000 \mathrm{~g}$ flour $(1 / 3$ wheat flour, $70 \%$ extraction rate, and $2 / 3$ whole wheat flour), $700 \mathrm{~mL}$ of water, $6 \mathrm{~g}$ of salt $(0.6 \%$ $w / w)$ and $4 \mathrm{~g}$ of commercial baker's yeast (GIOTIS S.A., Athens, Greece) added to the flour mix. The specific flour mixture was used to simulate the flour with an $85 \%$ extraction rate used for the preparation of sourdough, given the fact that baker's yeast works better with flour with a 70\% extraction rate. All above three types of flour used (70,85, 100\% extraction rate) are of commercial grade and were produced at St. George Mills, Ioannina, Greece. Then, the mixture was kneaded for $20 \mathrm{~min}$, and the dough was left to rest at $25{ }^{\circ} \mathrm{C}$ for $50 \mathrm{~min}$. Then, the mature dough was baked in a preheated home-type stove oven at $175^{\circ} \mathrm{C}$ for $90 \mathrm{~min}$. The resulting bread loaf weighed $1300 \mathrm{~g}$. For the preparation of sourdough bread, to the above flour mixture, $200 \mathrm{~g}$ of sourdough, $6 \mathrm{~g}$ salt, and water were added, and the mixture was kneaded for $20 \mathrm{~min}$. The dough formed was left to rest at $25{ }^{\circ} \mathrm{C}$ for $5 \mathrm{~h}$ $15 \mathrm{~min}$. Then, the mature dough was baked as stated for the control bread. Bread loaves, five for each type of bread of parallelepiped shape, were stored in a bread basket away from direct light, at $25^{\circ} \mathrm{C} / 60 \%$ Relative Humidity (RH). Sampling of bread for all analyses was carried out every other day for up to 18 days (days $0,2,4,6,8,1012,14,16$, and 18). Both YLB and SDB prepared were reduced sodium breads [15]. Bread loaves were sliced ( $3 \mathrm{~cm}$ thick), and all were samples collected came from the inner parts of the loaf. The first sampling was carried out $1 \mathrm{~h}$ after the removal of bread from the oven.

\subsection{Microbiological Analysis}

\subsubsection{Bread Microflora}

The following groups of microbiota were determined in breads according to official protocols [16]. Total viable counts (TVC), yeasts/molds, Bacillus cereus, LAB, and Enterobacteriaceae. All plates were examined visually for typical colony types and morphological characteristics associated with each growth medium. In addition, the selectivity of each medium was checked routinely by Gram staining and microscopic examination of smears prepared from randomly selected colonies from all of the media. TVC was determined using Plate Count Agar (PCA, Merck, Darmstadt, Germany). Colonies were counted after incubation at $30^{\circ} \mathrm{C}$ for $48 \mathrm{~h}$. Yeasts $/$ molds were determined using the non-selective medium Rose Bengal Chloramphenicol agar (RBC, Merck). Colonies were counted after incubation at $30^{\circ} \mathrm{C}$ for 4 days. Bacillus cereus was determined using the selective medium Mannitol Egg Yolk Polymyxin Agar (MYP, Oxoid) containing $50 \mathrm{~mL}$ egg yolk emulsion and 2 ampules of Polymyxin B supplement. Colonies were counted after incubation at $37^{\circ} \mathrm{C}$ after 3 days. LAB were determined using the selective medium Man Rogosa Sharpe medium (MRS, Merck). Colonies were counted after incubation at $37{ }^{\circ} \mathrm{C}$ after 3 days. Finally, for members of the family Enterobacteriaceae, $1.0 \mathrm{~mL}$ sample was inoculated into $15 \mathrm{~mL}$ of molten $\left(45^{\circ} \mathrm{C}\right)$ violet red bile glucose agar (Oxoid). After setting, a $10 \mathrm{~mL}$ overlay of molten medium was added, and incubation was carried out at $37^{\circ} \mathrm{C}$ for $24 \mathrm{~h}$. 


\subsubsection{Sourdough Microbiota-Library Construction and Sequencing}

DNA was extracted from $200 \mathrm{mg}$ sourdough using the ZymoBIOMICS DNA Miniprep Kit (ZYMO RESEARCH; Irvine, CA, USA) according to the manufacturer's instructions. DNA concentration was measured on a Qubit ${ }^{\mathrm{TM}} 4$ Fluorimeter using the Qubit ${ }^{\circledR}$ dsDNA BR assay kit (Invitrogen, Carlsbad, CA, USA). Bacterial diversity was assessed by sequencing the V3-V4 hypervariable regions of the 16S rRNA gene. For fungal diversity, two approaches were applied; sequencing of the V7-V8 hypervariable regions of the 18S rRNA and application of the internal transcribed spacer 1 (ITS1) genes to assess fungal load. For the amplification of the $16 \mathrm{~S}$ rRNA gene sequences, libraries were constructed using the primers D-Bact-0341-b-S-17 and D-Bact-0008-a-S-16 selected from Klindworth et al. [17]. For the amplification of the SSU of the 18S rRNA gene sequences, universal primers FR1 and FF390 were selected from Chemidlin Prevost-Boure et al. [18], whereas for ITS sequencing, primers BITS and B58S3 were selected from Bokulich and Mills [19]. All primers were modified by adding an Illumina (Illumina Inc, San Diego, CA, USA) overhang adapter nucleotide sequence at the $5^{\prime}$ end. Libraries were constructed as described in the Illumina's 16S Metagenomic Sequencing Library Preparation (15044223 B) protocol. Libraries were quantified through quantitative PCR (qPCR) with the KAPA Library Quantification kit for Illumina sequencing platforms (KAPA BIOSYSTEMS, Woburn, MA, USA). Sequencing was performed in a MiSeq platform, using the MiSeq ${ }^{\circledR}$ reagent kit v3 $(2 \times 300$ cycles $)$ (Illumina, San Diego, CA, USA).

\subsubsection{Amplicon Meta-Barcoding Bioinformatics Analysis}

Assessment of bacterial and fungal load was conducted using the Quantitative Insights into Microbial Ecology 2 (QIIME2) pipeline [20]. PCR primers were trimmed using the cutadapt plugin [21]. Trimming, de-noising, and chimera removal were conducted within QIIME2 with DADA2 R library [22]. Sequences were clustered into operational taxonomic units (OTUs) with 99\% sequence similarity and aligned to the SILVA 132 database for $16 \mathrm{~S}$ and $18 \mathrm{~S}$ rRNA sequences. For ITS analysis, sequences were aligned to the UNITE fungal ITS database version 7.2. OTU tables and biom files were imported in R version 3.6.0 [23] to further process and visualize results. OTU counts and taxonomic assignments were merged to a phyloseq object with phyloseq R package [24]. All plots were visualized by combining functions provided by the ggplot $2 \mathrm{R}$ package [25]. All bar plots were normalized to $100 \%$ as abundance estimations within each sample; thus, percentages do not reflect the true biomass fraction of each sample.

\subsection{Physicochemical Analysis}

\subsection{1. $\mathrm{pH} /$ Titratable Acidity (TA) Determination}

$\mathrm{pH}$ and TA expressed as $\mathrm{mL} 0.1 \mathrm{~N} \mathrm{NaOH}$ were determined in breads according to Latou et al. [26].

\subsubsection{Semi-Quantitative Determination of Flavor Volatiles of Bread}

Volatile compounds were identified and semi-quantified using the Solid Phase Micro Extraction GC/MS method as described by Latou et al. [26]. The sample consisted of $1 \mathrm{~g}$ of shredded bread (crumb and crust) and $20 \mu \mathrm{L}$ of 4-methyl-2-pentanol $(16.2 \mu \mathrm{g} / \mathrm{kg})$ as an internal standard.

\subsubsection{Determination of Water Activity}

Water activity $\left(\mathrm{a}_{\mathrm{W}}\right)$ of bread was determined using a Novasina model LabSwift- $\mathrm{a}_{\mathrm{W}}$ water activity meter (Lachen, SZ) at $20^{\circ} \mathrm{C}$.

\subsubsection{Determination of Texture Parameters (Texture Profile Analysis, TPA)}

Objective texture profile analysis of breads was carried out using an Instron Universal Testing Machine, model 4411 (Instron Corp., Bucks, UK) providing compressive load vs. time curves. Bread crumb samples in the form of cylindrical discs $(25 \mathrm{~mm}$ diame- 
ter $\times 20 \mathrm{~mm}$ in thickness) were prepared from the central part of each bread loaf. Then, samples were subjected to a double compression cycle using a $7.5 \mathrm{~cm}$ diameter stainless steel compression plunger. The crosshead speed was $100 \mathrm{~mm} / \mathrm{min}$, and the specimen compression depth was $60 \%$. Texture parameters determined included hardness, springiness, cohesiveness, gumminess, and chewiness. Of the above parameters, the present study focused on hardness (defined as the peak force of the first compression cycle, expressed in $\mathrm{N}$ ) and springiness (defined as the ratio of the time duration of force input during the second compression to that during the first compression, dimensionless) [27]. The Bluehill software (Version 1.4, Instron, Norwood, MA, U.S.A) was used to record texture profile analysis (TPA) data.

\subsection{Sensory Evaluation}

Sensory evaluation of breads (hedonic test) was conducted by a 51-member untrained panel consisting of graduate students of the Department of Chemistry according to Latou et al. [26]. Data on appearance, taste, aroma, and texture were collected every other day up to 18 days of storage (10 samplings in all). For testing, ca. $10 \mathrm{~g}$ of bread samples were placed in 3-digit randomly coded plastic cups and tightly capped. At each sampling day, along with the two test samples, panelists were given two reference samples consisting of bread taken from the same loaf (yeast leavened and sourdough bread) packed under N2 and stored in the dark at $2{ }^{\circ} \mathrm{C}$ up to 18 days. Prior to evaluation, samples were allowed to stand for $30 \mathrm{~min}$ in order to achieve the equilibration of volatile compounds in the cup headspace. Sensory scores were recorded on specially designed evaluation sheets using a 5 -point hedonic scale where $5=$ most liked and $1=$ most disliked sample. The lower limit of acceptability for all four sensory attributes was the score of 3 . On each sampling day, triplicate samples were evaluated for each treatment. If even one of the triplicate samples showed visible mold growth or if odor, taste, or texture received a score less than 3 , the sample was considered unacceptable.

\subsection{Statistical Analysis}

The experiment was replicated twice on different occasions using different bread samples. Triplicate samples were analyzed per replicate $(n=2 \times 3=6)$. Microbiological data were transformed into logarithms, expressed as $\log \mathrm{cfu} / \mathrm{g}$ ), and subjected to analysis of variance using the software SPSS 16 for windows. Results are reported as mean values \pm standard error or standard deviation. Tukey's test was used to assess differences between means and the significance of differences was considered at the level of $p<0.05$.

\section{Results and Discussion}

\subsection{Microbiological Analysis}

\subsubsection{Bread Microflora}

Bread is considered a sterile product being heated at a high temperature $\left(>170{ }^{\circ} \mathrm{C}\right)$ during baking. Thus, the presence of microbiota in bread is mostly due to post-baking contamination. The initial TVC for yeast leavened bread and sourdough bread was 2.9 and $<2.00 \log \mathrm{cfu} / \mathrm{g}$, respectively $(p<0.05)$ (Figure 1a). TVC exceeded the value of $6.0 \mathrm{log} \mathrm{cfu} / \mathrm{g}$, which was considered as the upper microbiological limit for bakery products, as defined by the International Commission on Microbiological Specifications for Foods (ICMSF) [28] on day 4 for conventional bread. In traditional sourdough bread, TVC increased slowly but remained lower than $3.5 \log \mathrm{cfu} / \mathrm{g}$ until day 18 of storage. It is obvious that TVC in sourdough bread remained quite lower $(p<0.05)$ than that of yeast leavened bread due to the substantially higher titratable acidity $(7.9-8.6 \mathrm{~mL} 0.1 \mathrm{~N} \mathrm{NaOH})$ and lower $\mathrm{pH}(\mathrm{pH}<6$, Figure $4 \mathrm{~b}$ ) of the former creating an effective hurdle to bacterial growth. 


\section{TVC}

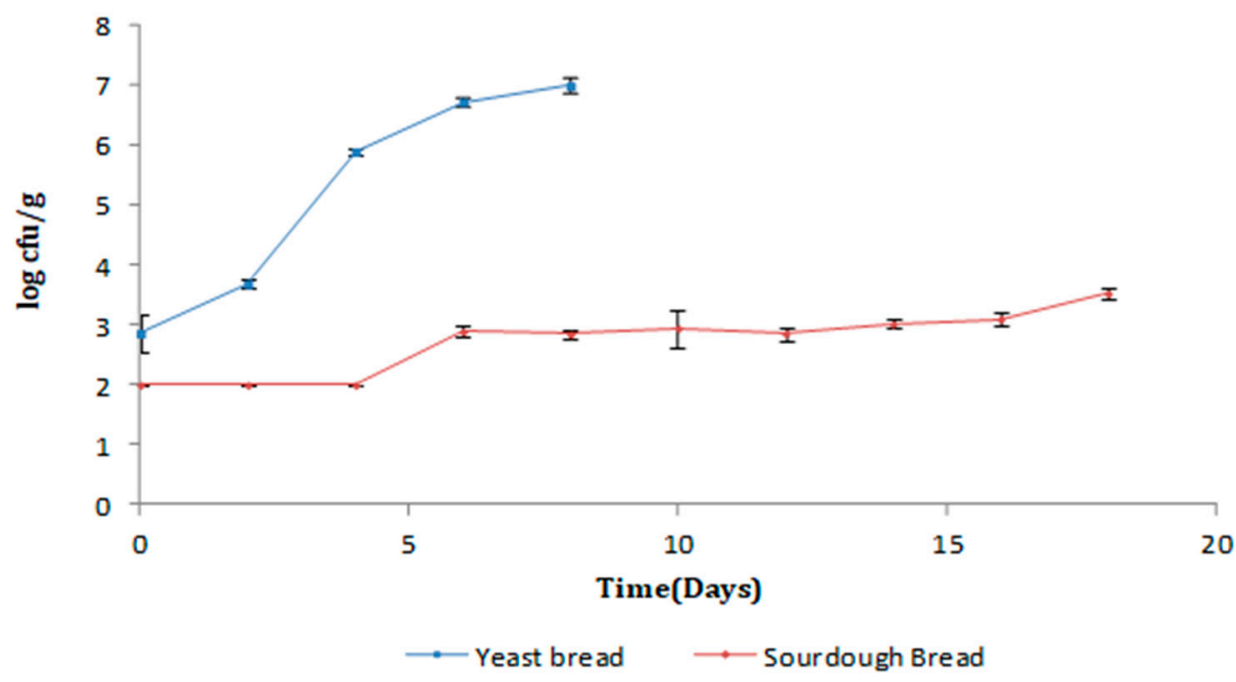

(a)

\section{Yeasts and molds}

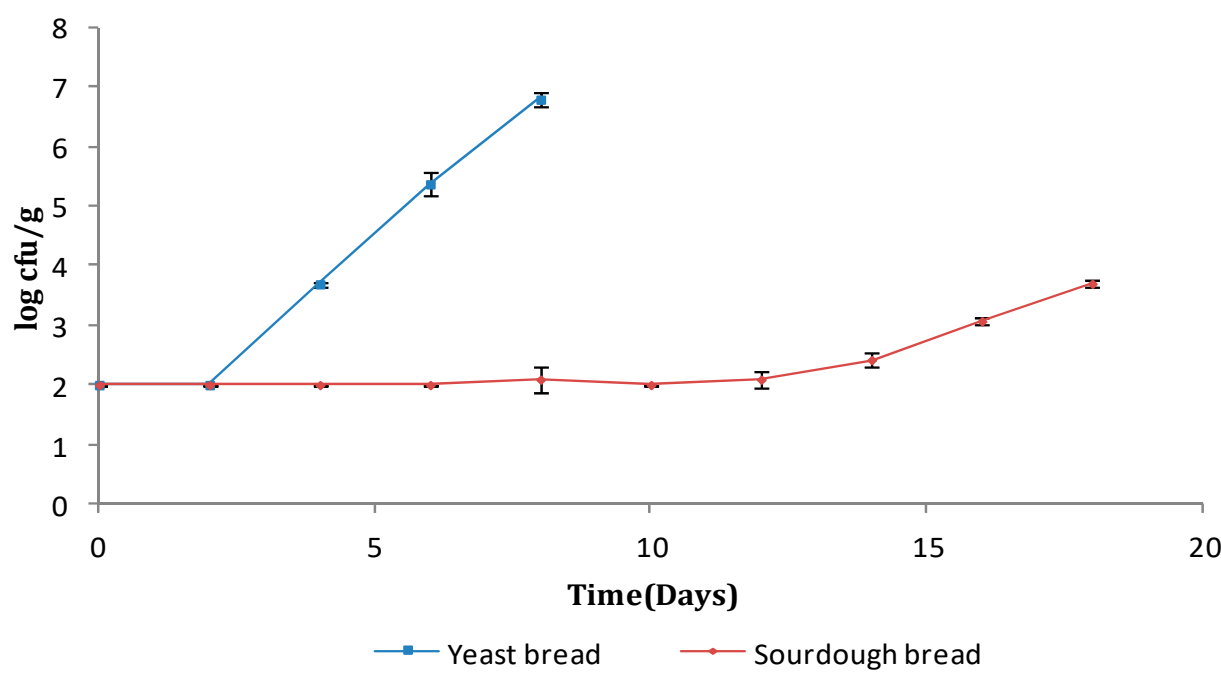

(b)

Figure 1. Cont. 


\section{Bacillus Cereus}

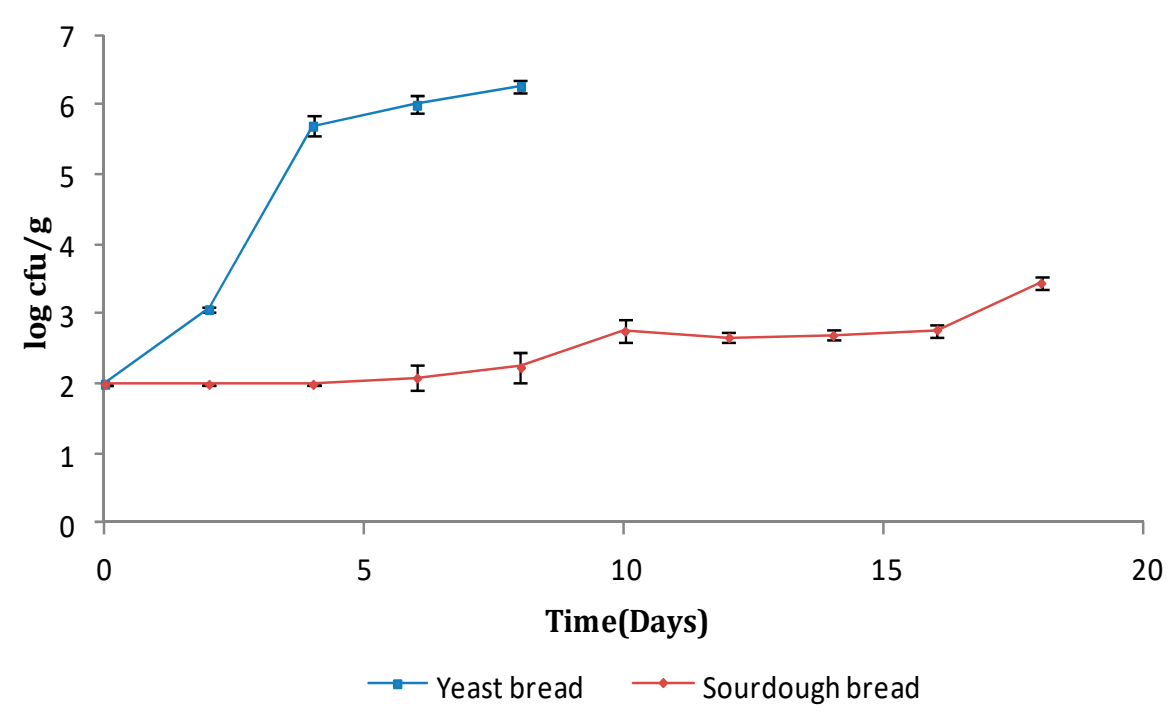

(c)

\section{Lactic acid bacteria}

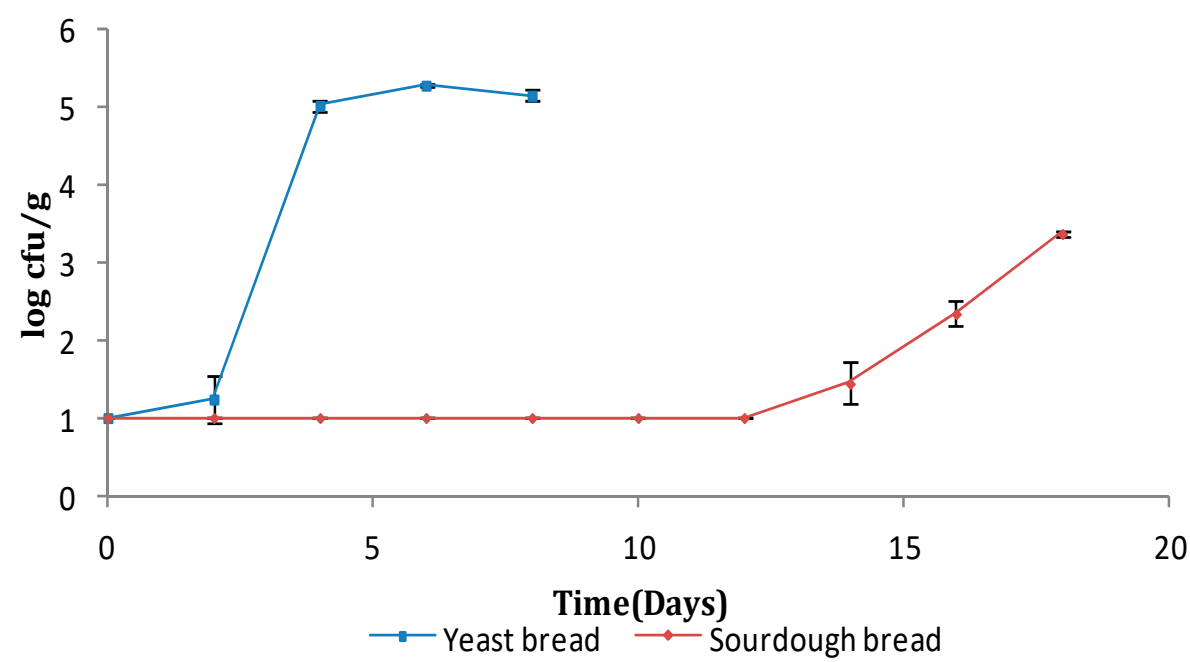

(d)

Figure 1. Changes in (a) total viable counts (TVC), (b) yeasts and molds, (c) Bacillus cereus, and (d) lactic acid bacteria (LAB) in yeast leavened and sourdough bread as a function of time.

Mohsen et al. [4] investigated the quality characteristics of Egyptian balady bread by using sourdough containing (2\% Saccharomyces cerevisiae plus 1,2, or 3\% Lactobacillus plantarum). TVC, LAB, yeasts, $\mathrm{pH}$, organic acids, and antimicrobial activity were evaluated during sourdough fermentation. Results showed an increase in organic acids, antimicrobial activity, and reduction in $\mathrm{pH}$ during the preparation of different sourdough samples. Bread characteristics showed an extented shelf life of 8 days for bread samples containing sourdough ( 2 or $3 \% \mathrm{Lb}$. plantarum) compared to 3 days for control bread. Improvements in the sensory characteristics and acceptability of balady bread were also recorded. The addition of $20 \%$ sourdough containing 2 or $3 \% \mathrm{Lb}$. plantarum to wheat flour dough also retarded the staling rate compared to control samples. Latou et al. [26] studied the effect of active 
packaging (addition of ethanol emitter/oxygen absorber) on shelf-life extension of sliced wheat bread stored at $20^{\circ} \mathrm{C}$. The TVC of control samples ranged between 3.0 and $7.2 \mathrm{log}$ $\mathrm{cfu} / \mathrm{g}$ after 10 days of storage. These values are in excellent agreement with those of the present study regarding yeast leavened bread. Jonkuvienè et al. [29] identified LAB naturally occurring in spontaneous sourdough and used them for quality improvement and prolonging the shelf life of rye, wheat + rye, and wheat bread. The identification of isolates from spontaneous sourdough by the pyrosequencing assay showed that Lactobacillus reuteri was the dominant lactic acid bacterium. $L b$. reuteri showed a high preserving capacity also against fungi during storage exhibiting high antimicrobial activity. The authors concluded that $L b$. reuteri has the potential to be used as a starter additive that could improve safety and enhance the shelf life of bread.

The initial count of yeasts/molds was lower than $2.0 \mathrm{log} \mathrm{cfu} / \mathrm{g}$ for both bread types reaching values of 6.8 and $3.7 \log \mathrm{cfu} / \mathrm{g}$ after 8 days for the control and 18 days for the sourdough bread (Figure $1 \mathrm{~b}$ ). The yeast/mold growth rate rose sharply beginning with days $2-3$ of storage for yeast bread, while a considerably lower $(p<0.05)$ yeast/mold growth rate was observed beginning with days 10-12 for sourdough bread. The explanation in this trend is similar to that for TVC - that is, the lower $\mathrm{pH} /$ higher titratable acidity of the sourdough bread inhibited the rapid growth of yeasts/molds. It should be noted that mold growth was apparent when the population of yeasts/molds reached approximately $4 \log \mathrm{cfu} / \mathrm{g}$. This observation is in agreement with Latou et al. [26]. This yeasts/molds count was reached on days $4-5$ for the control and day $18+$ for the sourdough bread. It is clear that the sourdough resulted in a drastic reduction of yeasts/molds populations. Fernandez et al. [30] reported a count of $3.0 \mathrm{log} \mathrm{cfu} / \mathrm{g}$ for yeasts/molds' visible growth in soy bread. Finally, Tatar et al. [31] prepared wheat bread with the addition of different levels of acidulants, i.e., acetic and lactic acid with calcium propionate. The study included microbiological analysis, sensory evaluation, and shelf-life determination. Storage for 4 days affected the aroma, taste, texture, and bread crust characteristics to a great extent. Treatments containing $0.2 \%$ and $0.3 \%$ lactic acid in combination with $0.2 \%$ calcium propionate were the most effective against microbial spoilage. TVC on day 4 ranged from 2.5 to $3.1 \log \mathrm{cfu} / \mathrm{g}$, while molds ranged from 3 to $3.5 \log \mathrm{cfu} / \mathrm{g}$. According to Samapundo et al. [32], fungal spoilage is a minor problem in the bakery industry today but has been causing trouble and losses for decades.

B. cereus is a Gram-positive, spore-forming, motile, facultative anaerobic bacterium causing both food spoilage in bread (ropy texture) and possibly food poisoning [33]. On day $0, B$. cereus counts were under the method detection limit $(2 \log \mathrm{cfu} / \mathrm{g})$, and at the time of visible signs of mold growth (days 4-5), they reached $5.8 \mathrm{log} \mathrm{cfu} / \mathrm{g}$ for control samples and $2.1 \log \mathrm{cfu} / \mathrm{g}$ for sourdough bread samples $(p<0.05)$ (Figure 1c). According to European Food Safety Authority (EFSA) [34], food-borne diseases caused by B. cereus have been associated with concentrations of at least $5 \log \mathrm{cfu} / \mathrm{g}$, which is a value that was exceeded in the present study only for the control bread sample on days $4-5$ of storage. B. cereus population reached $6.3 \log \mathrm{cfu} / \mathrm{g}$ in the control sample on day 8 of storage and $3.5 \log$ $\mathrm{cfu} / \mathrm{g}$ in sourdough bread on day 18 of storage. It is obvious that sourdough inhibits the growth of $B$. cereus due to the increased acidity of the bread matrix acting as a hurdle for bacterial growth. Latou et al. [26] reported a B. cereus count of $6 \mathrm{log} \mathrm{cfu} / \mathrm{g}$ for conventional air packaged bread on day 9 of storage. At the time of visible mold growth (day 5 of storage), the population of B. cereus was ca. $4 \log \mathrm{cfu} / \mathrm{g}$. Bailey and von Holy [35] studied the contamination of bread by Bacillus spp. and reported enhanced growth $(6.4 \log \mathrm{cfu} / \mathrm{g})$ on day 3 of storage at $30^{\circ} \mathrm{C}$. Differences in B. cereus populations between the research cited above and the present study are probably due to the lower storage temperature used in the present study ( 25 vs. $30^{\circ} \mathrm{C}$ ). Ravimannan [36] investigated the microbial profile of bread in Sri Lanka stored for 5 days at $29-31{ }^{\circ} \mathrm{C}$ and $70 \%$ relative humidity. After the initial fungal growth (mainly Mucor spp. and Rhizopus spp. after three days), the soft texture of the bread changed and became hard, during which the microbial load was dominated by bacteria. The bacterial species identified were B. cereus and B. subtilis. On day 3 of storage, 
the combined population of B. cereus and B. subtilis was $5.1 \log \mathrm{cfu} / \mathrm{g}$, while on day 5 of storage, the respective population was $6.3 \mathrm{log} \mathrm{cfu} / \mathrm{g}$. It was suggested by the authors that bread should be consumed during the first three days after preparation.

$\mathrm{LAB}$ are fermentative, facultative anaerobic bacteria that can grow both in the presence and absence of oxygen. They constitute the major part of sourdough microbiota and the major source of sourdough bread acidity. The initial LAB counts were lower than 1 log $\mathrm{cfu} / \mathrm{g}$ and reached ca. $5.2 \log \mathrm{cfu} / \mathrm{g}$ in the control sample on day 6 of storage (Figure 1d). On the same day, LAB counts remained under $1 \log \mathrm{cfu} / \mathrm{g}$ in the sourdough bread $(p<0.05)$. Starting with day 12 of storage, the LAB count began to increase in sourdough bread, reaching ca. $3.4 \log \mathrm{cfu} / \mathrm{g}$ on day 18. The large difference in LAB counts between yeast leavened and sourdough bread may be justified by the respective higher $\mathrm{pH}$ values in the former affecting LAB growth. Except for certain Lactobacillus spp., lactic acid bacteria are probably best characterized as neutrophiles with optimal growth rates ranging between 6.3 and 6.9 [37]. Park et al. [38] studied the LAB growth in Korean jeung-pyun (sponge-like sourdough bread cooked in steam) prepared by fermenting rice flour with rice wine. The study showed that LAB in sourdough (6-7 log cfu/g) play a key role in production of jeung-pyun bread, influencing the product textural and sensory properties.

Enterobacteriaceae comprises a large group of facultative anaerobic bacteria that are widely used as indicators of hygiene conditions prevailing in the food processing environment. The enterobacteriaceae remained below $1 \log \mathrm{cfu} / \mathrm{g}$ for all bread treatments during the 18 days of storage (data not shown). According to the New South Wales (NSW) Australian food authority, a count of Enterobacteriaceae $<10^{2} \mathrm{cfu} / \mathrm{g}$, is considered as good, $10^{2}$ to $<10^{4} \mathrm{cfu} / \mathrm{g}$ is considered acceptable, and $\geq 10^{4} \mathrm{cfu} / \mathrm{g}$ is regarded as unsatisfactory in ready-to-eat foods [39]. Both breads in the present study met this good quality criterion for the entire storage period.

Latou et al. [26] reported the same finding for sliced what bread stored both aerobically and under various active packaging conditions.

\subsubsection{Microbial Community in Sourdough}

The microbial community in sourdough was assessed using meta-barcoding analysis both for prokaryotic (16S rRNA) and eukaryotic organisms (18S rRNA and ITS genes). Sequencing of the $16 \mathrm{~S}$ rRNA gene resulted in 107.167 raw reads; after quality filtering and the removal of chimeric sequences, 70.145 reads were obtained. For eukaryotes, the sequencing of $18 \mathrm{~S}$ rRNA and ITS genes resulted in 143.801 and 76.328 raw reads, respectively. After quality filtering and the removal of chimeric reads, these numbers were reduced to 88.189 and 14.139 reads, respectively. The assignment and clustering of sequences against the reference databases resulted in 61 unique OTUs for bacteria, 13 unique OTUs derived from $18 \mathrm{~S}$ rRNA sequencing, and 75 unique OTUs derived from ITS sequencing (Table 1$)$.

Table 1. Number of raw and quality filtered reads, number of sequences after chimera removal, and number of identified operational taxonomic units (OTUs) for $16 \mathrm{~S}$ rRNA, $18 \mathrm{~S}$ rRNA, and internal transcribed spacer (ITS) amplicon sequencing.

\begin{tabular}{ccccc}
\hline Amplicon & Number of Raw Reads & $\begin{array}{c}\text { Number of Reads } \\
\text { after Quality Filtering }\end{array}$ & $\begin{array}{c}\text { Number of Reads after } \\
\text { Chimera Filtering }\end{array}$ & $\begin{array}{c}\text { Number of OTUs } \\
\text { Identified }\end{array}$ \\
\hline 16S & 107.167 & 72.435 & 70.145 & 61 \\
18S & 143.801 & 92.318 & 88.189 & 13 \\
ITS & 76.328 & 42.361 & 14.139 & 75 \\
\hline
\end{tabular}

The bacterial profile of sourdough revealed that it was dominated by Firmicutes (89.9\%) followed by Proteobacteria (7.05\%) and Cyanobacteria (2.86\%) (Figure 2a). Bacilli $(89.91 \%)$, Alphaproteobacteria (6.94\%), and Oxyphotobacteria $(2.86 \%)$ dominated the bacterial community at class level (Figure $2 \mathrm{~b}$ ). Overall, sourdough presented low bacterial diversity; genus Lactobacillus (89.91\%), mainly represented by L. sanfranciscensis spp. (89.67\%) was the dominant bacteria, followed by L. paralimentarius $(0.28 \%$ ) (Figure $2 \mathrm{~d}, \mathrm{e})$. 

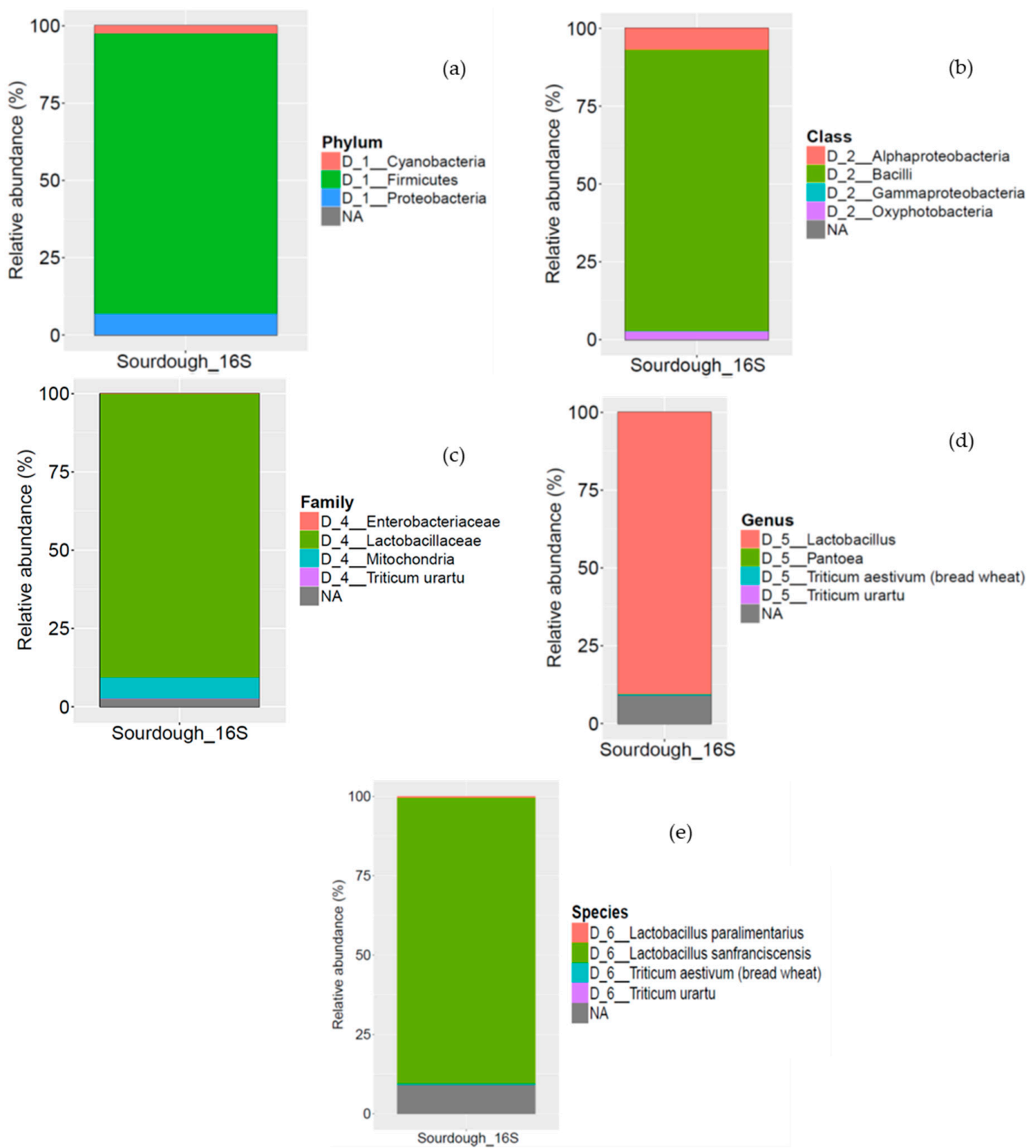

Figure 2. Analysis of prokaryotic community in sourdough (a), distribution of the major bacterial phyla, (b) distribution of the major bacteria at the class level, (c) distribution of the major bacteria at the family level, (d) distribution of the major bacteria at the genus level, and (e) distribution of the major bacteria at the species level. The scale in the y-axis reflects the normalized relative abundance percentages.

Analysis of the eukaryotic load identified a more complex profile for the sourdough, independently of the target region (18S rRNA or ITS genes). Yet, analysis of the ITS gene identified more OTUs, which are better characterized at the species level. Analysis of the 18S rRNA gene revealed that Opisthokonta was the major phylum being present with $75.73 \%$ relative abundance (data not shown). These fungi were further classified at the family level; Saccharomycetaceae (33.03\%), Pleosporaceae (17.52\%), and Cladosporiaceae $(11.86 \%)$ were the most abundant families present in sourdough (Figure $3 a)$. At the genus level, 18S rRNA analysis revealed that Saccharomyces (33.03\%) was the dominant genus, followed by Alternaria (12.22\%), Cladosporium (11.86\%), and Fusarium $(1.82 \%)$ genera (Figure $3 \mathrm{~b}$ ). At the species level, 18S rRNA analysis against SILVA 132 could not detect any fungi. Although $18 \mathrm{~S}$ rRNA analysis identified the main bacteria at the genus level, analysis of the ITS gene provided much more information on the fungal load of sourdough. In particular, Saccharomycetaceae (28.81\%), Pleosporaceae (21.93\%), and Mycosphaerellaceae 
(2.23\%) were the most abundant families (Figure 3c). At the genus level, Saccharomyces (28.81\%) and Alternaria (20.31\%) were the most abundant genera, followed by Mycosphaerella $(2.23 \%)$ (Figure $3 \mathrm{~d})$. These genera were mainly represented in sourdough by $\mathrm{S}$. cerevisiae $(28.81 \%)$, A. hordeicola $(5.88 \%)$, and M. tassiana $(2.23 \%)$, respectively (Figure 3e). It is noteworthy that a large fraction of the eukaryotic load $(41.25 \%)$ could not be identified at the genus level. To the best of our knowledge A. hordeicola and M. tassiana have not been previously reported in traditional sourdoughs.
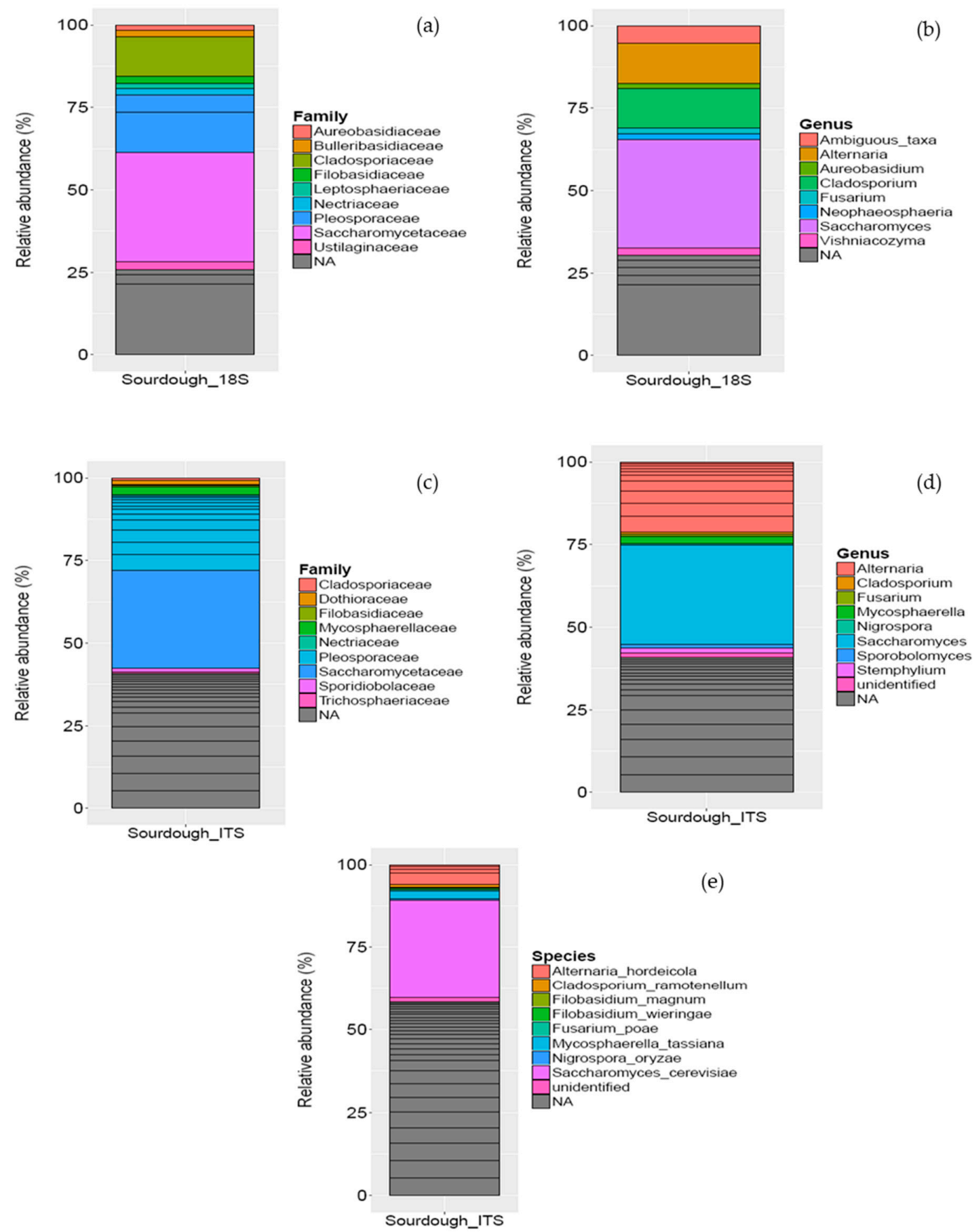

Figure 3. Analysis of the eukaryotic community in sourdough by sequencing the 18S rRNA gene (a) distribution of the major fungal families, (b) distribution of the major fungal genera. (c) Analysis of eukaryotic community in sourdough by sequencing the ITS gene. Distribution of the major fungal families, (d) distribution of the major eukaryotic genera, and (e) distribution of the major eukaryotic species. The scale in the y-axis reflects the normalized relative abundance percentages (\%). Black lines within each bar separates each species into lower taxonomic levels. 
The above results are in general agreement with those of De Vuyst et al. [40], who isolated bacteria into the species Lactobacillus sanfranciscensis, Lactobacillus brevis, Lactobacillus paralimentarius, and Weissella cibaria. This consortium according to these authors seems to be unique for the Greek traditional wheat sourdoughs studied. Strains of the species $W$. cibaria have not been isolated from sourdoughs previously. Studies dealing with the identification and characterization of LAB from traditional sourdoughs revealed the dominance of L. sanfranciscensis strains in type I sourdoughs, which were probably selected only by the environmental conditions induced by the sourdough fermentation technology. However, many researchers still report the existence of unidentifiable and perhaps new sourdough LAB species. Palla et al. [41] characterized sourdough microbiota used to produce Protected Designation of Origin (PDO) Tuscan bread and reported a large number of L. sanfranciscensis and C. milleri strains, along with a few of S. cerevisiae. Lhomme et al. [42] characterized 16 sourdoughs used for the manufacture of traditional French breads. Lactobacillus sanfranciscensis was found to be the dominant species in French sourdoughs. In addition to species frequently encountered (e.g., Lactobacillus parabrevis/Lactobacillus hammesii, Lactobacillus plantarum, and Leuconostoc mesenteroides), Lactobacillus xiangfangensis and Lactobacillus diolivorans were also found in sourdough. Yeast diversity was lower than LAB. Except for one sourdough (solely dominated by Kazachstania servazzii), the yeast microbiota of French sourdoughs was dominated by Saccharomyces cerevisiae. Finally, according to De Vuyst et al. [8], no clear-cut relationship between a typical sourdough and its associated microbiota can be found, as this is dependent on the sampling, isolation, and identification procedures. Both simple and very complex consortia may be encountered. Moreover, intrinsic and extrinsic factors may influence the composition of the sourdough microbiota such as the flour (type, quality status, etc.) and the process parameters (temperature, $\mathrm{pH}$, dough yield, backslopping practices, etc.)

\subsection{Physico-Chemical Analysis \\ 3.2.1. $\mathrm{TA} / \mathrm{pH} / \mathrm{a}_{\mathrm{w}}$}

The initial TA of sourdough bread was 7.9, increasing to $8.7 \mathrm{~mL} \mathrm{NaOH} 0.1 \mathrm{~N}$ on day 18 of storage (Figure $4 \mathrm{a}$ ). Initial TA values for the yeast leavened bread were 4.0 , increasing to $6.7 \mathrm{~mL} \mathrm{NaOH} 0.1 \mathrm{~N}$ on day 8 of storage. On day 0 , the $\mathrm{pH}$ of yeast leavened bread was 6.8 , decreasing to 6.4 on day 8 of storage. The initial $\mathrm{pH}$ value of sourdough bread was 5.7, remaining practically constant and decreasing to 5.5 on day 18 of storage (Figure $4 \mathrm{~b}$ ). The results regarding TA are in line with the maximum growth of acid-producing LAB after days 2-3 for yeast leavened bread and after day 12 for sourdough bread (Figure 1d). The results regarding $\mathrm{pH}$ are in agreement with both LAB growth curves (Figure 1d) and TA curves (Figure $4 \mathrm{a}$ ); i.e., $\mathrm{pH}$ values begin to decrease $(p<0.05)$ after ca. day 3 of storage (with a simultaneous increase in TA) for the yeast leavened bread and begin to decrease $(p<0.05)$ after days 14-15 of storage (with a simultaneous increase TA) for the sourdough bread.

Banu et al. [43] prepared rye bread with $20 \%$ sourdough using $L b$. plantarum and $L b$. brevis. Rye bread without sourdough was taken as the control. The sourdough rye bread had a lower $\mathrm{pH}$ and a higher TA ( $\mathrm{pH}$ from 5.1 to 5.3, and TA from 5 to $5.4 \mathrm{~mL} \mathrm{NaOH}$ $0.1 \mathrm{~N}$ ), in comparison to control rye bread sample (pH 6.1, and TA $2.5 \mathrm{~mL} \mathrm{NaOH} \mathrm{0.1} \mathrm{N).}$ Mert et al. [44] investigated the effect of the addition of different amounts of sourdough $(0 \%, 20 \%$, and $40 \%$ of flour basis) on the quality parameters ( $\mathrm{pH}, \mathrm{TA}$, firmness, and volume) of chestnut-rice gluten-free breads. $\mathrm{pH}$ and TA of the control was 6.4 and $3.0 \mathrm{~mL} \mathrm{NaOH}$ $0.1 \mathrm{~N}$, respectively. $\mathrm{pH}$ and TA were 5.4 and $5.2 \mathrm{~mL} \mathrm{NaOH} 0.1 \mathrm{~N}$, respectively, for bread made of $20 \%$ sourdough. The respective values for bread made of $40 \%$ sourdough were $\mathrm{pH}=4.9$ and $\mathrm{TA}=7.0 \mathrm{~mL} \mathrm{NaOH} 0.1 \mathrm{~N}$. Likewise, Sanz-Penella et al. [45] used Bifidibacterium pseudocatenulatum as a starter culture in the preparation of sourdough, which was added at different ratios (0-20\%) to whole wheat flour to prepare bread. The $\mathrm{pH} / \mathrm{TA}$ values of the control bread were 5.7/4.2 mL NaOH 0.1 N. Respective values for the $\mathrm{pH}$ of sourdough breads ranged between 5.0 and 5.5 and for TA between 5.7 and $10.6 \mathrm{~mL} \mathrm{NaOH} 0.1 \mathrm{~N}$. Finally, Marcus et al. [46] reported a $\mathrm{pH}=6.0$ and $\mathrm{TA}=2.8 \mathrm{~mL} \mathrm{NaOH} 0.1 \mathrm{~N}$ for control 
bread and a $\mathrm{pH}=5.0$ and $\mathrm{TA}=5.0 \mathrm{~mL} \mathrm{NaOH} 0.1 \mathrm{~N}$ for sourdough bread prepared with the antifungal strain Lactobacillus amylovorus containing $28.3 \%$ of sourdough. Differences between the $\mathrm{pH} / \mathrm{TA}$ values of the present study and the literature may be related to the type of sourdough culture used, ratio of sourdough/flour, temperature of sourdough fermentation, type of flour used, etc.

TA

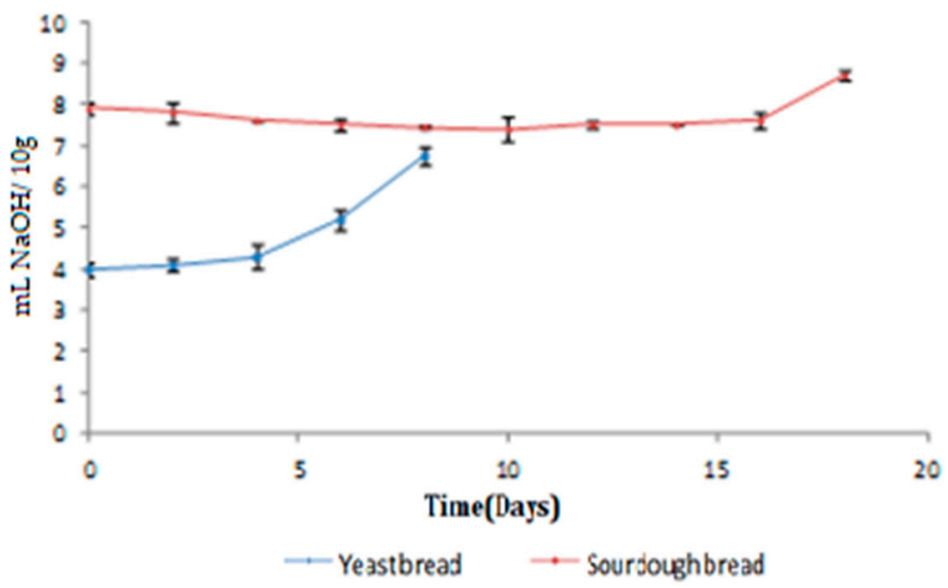

(a)

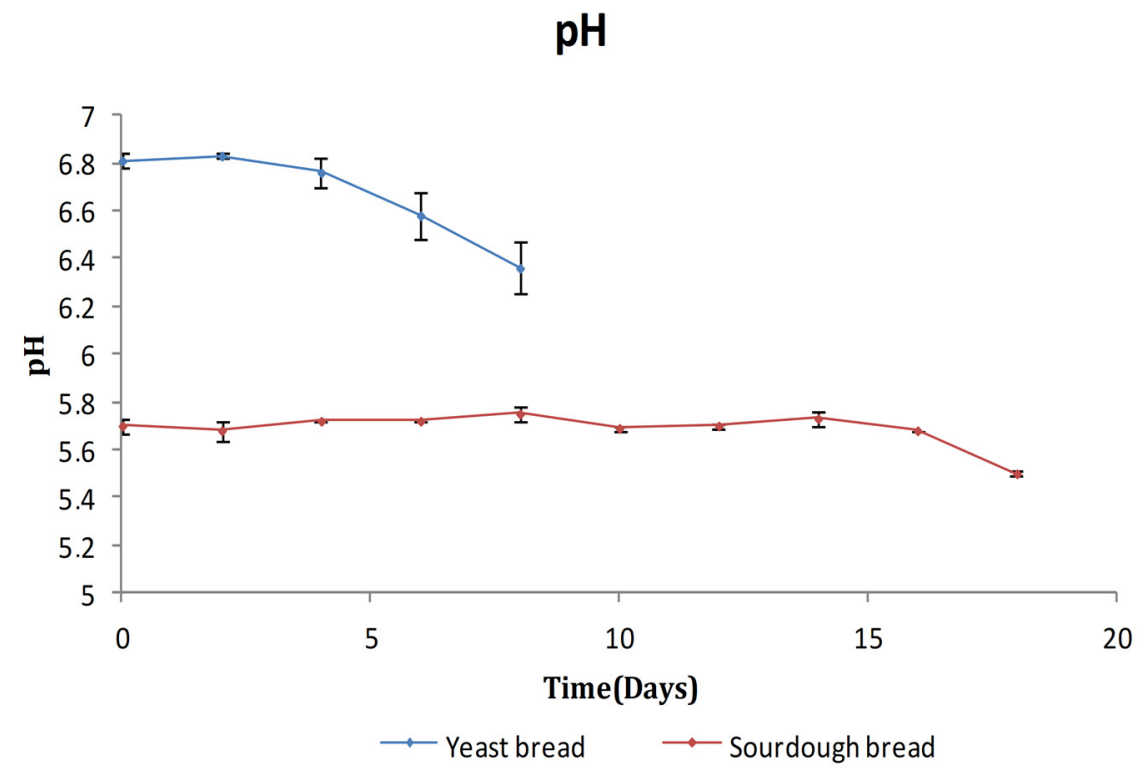

(b)

Figure 4. Changes in (a) titratable acidity and (b) $\mathrm{pH}$ in yeast leavened and sourdough bread as a function of time.

Water activity values for control and sourdough bread were 0.983 and 0.981 , respectively. The lower $\mathrm{a}_{\mathrm{w}}$ values $(p<0.05)$ in sourdough bread reflect the longer product shelf life compared to yeast leavened bread. Marcus et al. [46] reported $a_{w}$ values of 0.982 for control bread and 0.980 for sourdough bread at a $\mathrm{NaCl}$ content of $0.6 \%$. Respective values for a $\mathrm{NaCl}$ content of $1.2 \%$ were 0.974 and $0.972 . \mathrm{NaCl}$ is hygroscopic in nature, and therefore, the level of $\mathrm{NaCl}$ added to bread will have an impact on the water activity, which has previously been shown to affect microbial growth. Present $\mathrm{a}_{\mathrm{w}}$ values are in agreement with those (0.96-0.98) published in the literature [47,48]. 


\subsubsection{Volatile Compounds}

Reaction pathways for aroma formation in bread include volatiles formed (i) during fermentation (LAB and yeast activity), (ii) as a result of lipid oxidation, and (iii) from Maillard and caramelization reactions [49]. Furthermore, volatiles such as aldehydes and their corresponding alcohols are formed inside the yeast cells from the degradation of flour amino acids via the Ehrlich pathway [50]. Major volatiles formed during dough fermentation include alcohols, organic acids, esters, aldehydes, ketones, lactones, etc. mainly originating from precursors including carbohydrates and amino acids. The respective volatiles formed during lipid oxidation include aldehydes and ketones originating from the decomposition of triglycerides and fatty acids. Finally, volatiles formed from Maillard and caramelization reactions include pyrazines, pyridines, pyrroles, furans, sulfur compounds, aldehydes, and ketones originating from precursors including amino acids, peptides, and carbohydrates [3].

In total, 27 and 33 volatile compounds were determined in sourdough and yeast leavened bread, respectively. These belong to the chemical classes of aldehydes, ketones, alcohols, esters, organic acids, hydrocarbons, aromatic compounds, and sulfur compounds. The formation of these compounds as a function of time is given in (Tables 2 and 3 and Figure 5). According to Hansen and Hansen [51], sourdough bread should have more volatile compounds than yeast leavened bread or at least higher volatile contents.

Table 2. Effect of storage time on evolution of volatile $(\mu \mathrm{g} / \mathrm{kg})$ in sourdough bread stored at $25^{\circ} \mathrm{C}$.

\begin{tabular}{|c|c|c|c|c|c|c|c|c|}
\hline & Day 0 & Day 4 & Day 8 & Day 12 & Day 16 & Day 18 & KIEx & KILt \\
\hline \multicolumn{9}{|c|}{ Alcohols } \\
\hline Ethanol & $335.50 \pm 1.28 c$ & $343.40 \pm 2.20 c$ & $219.30 \pm 3.50 \mathrm{~b}$ & $214.70 \pm 2.96 b$ & $212.80 \pm 3.08 b$ & $190.50 \pm 7.40 \mathrm{a}$ & $<500$ & $<500$ \\
\hline $\begin{array}{l}\text { 2-Methyl-1- } \\
\text { propanol }\end{array}$ & $6.13 \pm 0.07 c$ & $5.33 \pm 0.43 b c$ & $4.74 \pm 0.12 \mathrm{ab}$ & $4.20 \pm 0.15 \mathrm{a}$ & $4.24 \pm 0.58 \mathrm{a}$ & $4.16 \pm 0.11 \mathrm{a}$ & 623 & 625 \\
\hline $\begin{array}{l}\text { 3-Methyl-1- } \\
\text { butanol }\end{array}$ & $73.45 \pm 1.00 \mathrm{a}$ & $69.69 \pm 5.87 \mathrm{a}$ & $47.49 \pm 3.83 b$ & $40.79 \pm 0.41 \mathrm{ab}$ & $38.22 \pm 0.25 \mathrm{a}$ & $38.11 \pm 0.16 \mathrm{a}$ & 734 & 743 \\
\hline $\begin{array}{l}\text { 2-Methyl-1- } \\
\text { butanol }\end{array}$ & $14.20 \pm 2.10 \mathrm{~d}$ & $12.86 \pm 1.36 \mathrm{~d}$ & $9.54 \pm 0.59 \mathrm{a}$ & $7.25 \pm 0.22 \mathrm{a}$ & $8.28 \pm 0.31 \mathrm{a}$ & $7.79 \pm 0.25 \mathrm{a}$ & 738 & 748 \\
\hline 1-Pentanol & $7.01 \pm 0.16 b$ & $6.70 \pm 0.39 \mathrm{~b}$ & $4.69 \pm 0.23 \mathrm{a}$ & $4.67 \pm 0.23 \mathrm{a}$ & $4.50 \pm 0.06 \mathrm{a}$ & $3.86 \pm 0.82 \mathrm{a}$ & 765 & 766 \\
\hline 1-Hexanol & $28.44 \pm 1.66 \mathrm{c}$ & $28.03 \pm 2.01 c$ & $18.68 \pm 1.97 \mathrm{ab}$ & $19.46 \pm 1.01 \mathrm{ab}$ & $21.42 \pm 1.29 b$ & $15.80 \pm 0.56 \mathrm{a}$ & 867 & 862 \\
\hline 1-Octen-3-ol & n.d. & n.d. & n.d. & n.d. & n.d. & $57.53 \pm 30.10 \mathrm{~b}$ & 981 & 978 \\
\hline Sum & $464.73 \pm 1.28$ & $466.01 \pm 2.75$ & $304.74 \pm 2.28$ & $291.07 \pm 1.30$ & $289.46 \pm 1.40$ & $317.75 \pm 3.05$ & & \\
\hline \multicolumn{9}{|c|}{ Aldehydes } \\
\hline $\begin{array}{l}\text { 3-Methyl-1- } \\
\text { butanal }\end{array}$ & $15.85 \pm 0.44 \mathrm{~d}$ & $4.03 \pm 0.47 \mathrm{c}$ & $3.35 \pm 0.01 b c$ & $1.92 \pm 0.44 \mathrm{a}$ & $2.56 \pm 0.13 \mathrm{ab}$ & $2.90 \pm 0.46 \mathrm{ab}$ & 656 & 650 \\
\hline Hexanal & $26.63 \pm 1.38 \mathrm{~d}$ & $14.69 \pm 2.65 c$ & $11.28 \pm 0.17 b c$ & $10.86 \pm 0.20 \mathrm{~b}$ & $12.46 \pm 0.45 b c$ & $6.23 \pm 1.17 \mathrm{a}$ & 802 & 798 \\
\hline Furfural & $10.70 \pm 1.60 c$ & $9.78 \pm 1.51 \mathrm{c}$ & $3.38 \pm 0.11 \mathrm{~b}$ & $1.08 \pm 0.54 \mathrm{ab}$ & n.d. & n.d. & 840 & 831 \\
\hline Heptanal & $8.61 \pm 0.18 c$ & $5.71 \pm 1.35 b$ & $2.80 \pm 0.32 \mathrm{a}$ & $3.59 \pm 0.24 \mathrm{a}$ & $2.99 \pm 0.17 \mathrm{a}$ & $2.20 \pm 0.27 \mathrm{a}$ & 904 & 901 \\
\hline Benzaldehyde & $10.15 \pm 0.87 c$ & $9.39 \pm 0.79 c$ & $3.92 \pm 1.86 \mathrm{~b}$ & $6.58 \pm 0.35 c$ & $4.40 \pm 0.79 \mathrm{bc}$ & n.d. & 980 & 970 \\
\hline Octabal & $2.95 \pm 0.43 c$ & $2.90 \pm 0.67 \mathrm{bc}$ & $1.60 \pm 0.13 \mathrm{a}$ & $1.93 \pm 0.12 \mathrm{ab}$ & $2.32 \pm 0.36 \mathrm{abc}$ & $4.04 \pm 0.06 \mathrm{~d}$ & 1007 & 1004 \\
\hline Nonanal & n.d. & $2.55 \pm 0.39 \mathrm{ab}$ & $3.12 \pm 0.29 b$ & $9.42 \pm 2.37 c$ & $12.41 \pm 1.03 \mathrm{~d}$ & n.d. & 1109 & 1099 \\
\hline Sum & $74.89 \pm 0.96$ & $49.05 \pm 1.34$ & $29.45 \pm 0.72$ & $35.28 \pm 0.95$ & $37.14 \pm 0.59$ & $15.37 \pm 0.64$ & & \\
\hline \multicolumn{9}{|c|}{ Ketones } \\
\hline $\begin{array}{l}\text { 2-Pentyl- } \\
\text { furanone }\end{array}$ & $3.15 \pm 2.23 \mathrm{a}$ & $2.62 \pm 0.61 \mathrm{a}$ & $1.18 \pm 0.37 \mathrm{a}$ & $2.19 \pm 0.04 a$ & $1.94 \pm 0.02 \mathrm{a}$ & $6.61 \pm 0.64 b$ & 993 & 989 \\
\hline \multicolumn{9}{|c|}{ Esters } \\
\hline $\begin{array}{l}\text { Butanoic } \\
\text { acid, methyl } \\
\text { ester }\end{array}$ & $4.36 \pm 0.29 \mathrm{~d}$ & $1.95 \pm 0.21 \mathrm{a}$ & $2.12 \pm 0.07 \mathrm{ab}$ & $2.61 \pm 0.20 \mathrm{bc}$ & $2.09 \pm 0.18 \mathrm{a}$ & $3.12 \pm 0.08 \mathrm{c}$ & 721 & 735 \\
\hline Sum & $4.36 \pm 0.29$ & $1.95 \pm 0.21$ & $2.12 \pm 0.07$ & $2.61 \pm 0.20$ & $2.09 \pm 0.18$ & $3.12 \pm 0.08$ & & \\
\hline
\end{tabular}


Table 2. Cont

\begin{tabular}{|c|c|c|c|c|c|c|c|c|}
\hline & Day 0 & Day 4 & Day 8 & Day 12 & Day 16 & Day 18 & KIEx & KILt \\
\hline \multicolumn{9}{|c|}{ Organic Acids } \\
\hline Acetic acid & $115.90 \pm 6.10 \mathrm{abc}$ & $99.30 \pm 14.5 \mathrm{a}$ & $131.00 \pm 6.68 \mathrm{bc}$ & $137.14 \pm 5.90 \mathrm{c}$ & $122.90 \pm 6.90 \mathrm{bc}$ & $113.24 \pm 2.40 \mathrm{ab}$ & 581 & 608 \\
\hline \multicolumn{9}{|c|}{ Hydrocarbons } \\
\hline Heptane & $6.09 \pm 0.31 b$ & $4.24 \pm 0.09 \mathrm{a}$ & $4.17 \pm 0.27 \mathrm{a}$ & $3.59 \pm 0.04 \mathrm{a}$ & $3.87 \pm 0.19 \mathrm{a}$ & $4.75 \pm 1.28 \mathrm{ab}$ & 698 & 700 \\
\hline Nonane & $2.37 \pm 0.09 c$ & $1.45 \pm 0.08 \mathrm{~b}$ & $1.20 \pm 0.05 \mathrm{ab}$ & $1.49 \pm 0.27 b$ & $0.86 \pm 0.04 \mathrm{a}$ & $2.55 \pm 0.07 c$ & 901 & 900 \\
\hline Decane & n.d. & $3.02 \pm 0.49 \mathrm{ab}$ & $1.70 \pm 0.62 \mathrm{~b}$ & $3.29 \pm 0.16 c$ & $2.05 \pm 0.02 b c$ & $32.14 \pm 0.95 \mathrm{~d}$ & 1001 & 1000 \\
\hline Dodecane & n.d. & n.d. & $0.88 \pm 0.44 \mathrm{a}$ & n.d. & n.d. & $9.82 \pm 0.84 b$ & 1202 & 1200 \\
\hline Tetradecane & n.d. & n.d. & $3.51 \pm 0.51 c$ & $1.86 \pm 0.37 b$ & n.d. & n.d. & 1403 & 1400 \\
\hline dl-Limonene & $1.30 \pm 0.35 \mathrm{a}$ & $1.22 \pm 0.35 \mathrm{a}$ & $0.97 \pm 0.01 \mathrm{a}$ & $1.40 \pm 0.27 \mathrm{a}$ & $4.87 \pm 0.81 \mathrm{~b}$ & $3.78 \pm 0.43 b$ & 1043 & 1039 \\
\hline $\begin{array}{c}\text { gamma- } \\
\text { Terpinene }\end{array}$ & $4.33 \pm 1.69 c$ & $2.20 \pm 0.62 b$ & n.d. & n.d. & n.d. & n.d. & 1070 & 1062 \\
\hline Sum & $14.09 \pm 0.88$ & $12.13 \pm 0.39$ & $12.43 \pm 0.39$ & $11.63 \pm 0.25$ & $11.65 \pm 0.42$ & $53.04 \pm 0.82$ & & \\
\hline \multicolumn{9}{|c|}{ Aromatic compounds } \\
\hline $\begin{array}{l}\text { 2-Pentyl-furan } \\
\text { p-Cymene }\end{array}$ & $\begin{array}{c}19.82 \pm 0.22 \mathrm{~d} \\
2.97 \pm 0.58 \mathrm{c}\end{array}$ & $\begin{array}{l}12.85 \pm 1.74 \mathrm{c} \\
2.71 \pm 0.70 \mathrm{bc}\end{array}$ & $\begin{array}{c}5.08 \pm 0.29 \mathrm{a} \\
1.89 \pm 0.23 \mathrm{abc}\end{array}$ & $\begin{array}{c}5.26 \pm 0.26 \mathrm{a} \\
1.82 \pm 0.25 \mathrm{ab}\end{array}$ & $\begin{array}{l}4.10 \pm 0.34 \mathrm{a} \\
0.85 \pm 0.11 \mathrm{a}\end{array}$ & $\begin{array}{c}7.99 \pm 0.77 b \\
10.70 \pm 0.29 d\end{array}$ & $\begin{array}{c}994 \\
1037\end{array}$ & $\begin{array}{c}992 \\
1026\end{array}$ \\
\hline Sum & $22.79 \pm 0.44$ & $15.56 \pm 1.32$ & $6.79 \pm 0.26$ & $7.08 \pm 0.25$ & $4.95 \pm 0.25$ & $18.69 \pm 0.58$ & & \\
\hline \multicolumn{9}{|c|}{ Sulfur compounds } \\
\hline $\begin{array}{l}\text { Dimethyl- } \\
\text { disulfide }\end{array}$ & n.d. & n.d. & $0.62 \pm 0.44 b$ & n.d. & n.d. & $0.46 \pm 0.32 \mathrm{ab}$ & 751 & 746 \\
\hline
\end{tabular}

n.d. = not detected. The values are the means of 6 measurements, $(n=6) \pm$ S.D., a.b.c Means with different letters in the same row are statistically different $(p<0.05)$, KIEx = Kovac Index experimentally determined data, KILi = Kovac Index literature data, Nist 05, J. Wiley \& Sons Ltd., West Sussex, England.

Table 3. Effect of storage time on evolution of volatile $(\mu \mathrm{g} / \mathrm{kg})$ in yeast leavened bread stored at $25^{\circ} \mathrm{C}$.

\begin{tabular}{|c|c|c|c|c|c|c|c|}
\hline Compounds & Day 0 & Day 2 & Day 4 & Day 6 & Day 8 & KIEx & KILt \\
\hline \multicolumn{8}{|c|}{ Alcohols } \\
\hline Ethanol & $447.60 \pm 6.30 \mathrm{~d}$ & $462.20 \pm 15.97 \mathrm{~d}$ & $312.43 \pm 2.96 c$ & $274.20 \pm 7.63 b$ & $11.86 \pm 0.63 \mathrm{a}$ & - & - \\
\hline 1-Propanol & $1.42 \pm 0.36 \mathrm{~b}$ & $1.42 \pm 0.27 \mathrm{~b}$ & $1.19 \pm 0.04 b$ & n.d. & n.d. & 552 & 554 \\
\hline 2-Methyl-1-propanol & $37.26 \pm 1.37 c$ & $35.49 \pm 2.35 c$ & $22.98 \pm 2.49 b$ & $22.18 \pm 1.38 b$ & $14.02 \pm 0.59 \mathrm{a}$ & 623 & 625 \\
\hline 3-Methyl-1-butanol & $169.70 \pm 5.97 \mathrm{~d}$ & $169.60 \pm 5.72 \mathrm{~d}$ & $90.09 \pm 4.55 c$ & $67.98 \pm 2.49 \mathrm{~b}$ & $3.87 \pm 0.18 \mathrm{a}$ & 734 & 743 \\
\hline 2-Methyl-1-butanol & $88.46 \pm 2.69 \mathrm{~d}$ & $89.62 \pm 3.11 \mathrm{~d}$ & $46.86 \pm 5.95 c$ & $37.29 \pm 0.11 b$ & $7.86 \pm 0.69 \mathrm{a}$ & 738 & 748 \\
\hline 1-Pentanol & $4.01 \pm 0.65 c$ & $4.11 \pm 0.65 c$ & $2.36 \pm 0.17 b$ & n.d. & n.d. & 765 & 766 \\
\hline 1-Hexanol & $18.29 \pm 0.04 \mathrm{~d}$ & $17.31 \pm 1.07 \mathrm{~d}$ & $9.97 \pm 2.70 \mathrm{c}$ & $4.28 \pm 0.83 b$ & n.d. & 867 & 862 \\
\hline 1-Octen-3-ol & n.d. & n.d. & $4.70 \pm 2.00 \mathrm{~b}$ & n.d. & $88.35 \pm 2.42 c$ & 981 & 978 \\
\hline Sum & $766.74 \pm 3.48$ & $779.75 \pm 6.60$ & $490.58 \pm 3.21$ & $405.93 \pm 3.67$ & $125.96 \pm 1.19$ & & \\
\hline \multicolumn{8}{|c|}{ Aldehydes } \\
\hline 3-Methyl-1-butanal & $2.49 \pm 0.19 c$ & $1.24 \pm 0.09 \mathrm{~b}$ & $0.98 \pm 0.16 b$ & n.d. & $2.77 \pm 0.10 c$ & 656 & 650 \\
\hline Hexanal & $15.04 \pm 0.51 \mathrm{~d}$ & $11.74 \pm 0.32 c$ & $1.27 \pm 0.51 \mathrm{~b}$ & n.d. & n.d. & 802 & 798 \\
\hline Heptanal & $6.94 \pm 0.45 \mathrm{~b}$ & $7.29 \pm 0.91 b$ & $0.46 \pm 0.02 \mathrm{a}$ & n.d. & n.d. & 904 & 901 \\
\hline Benzaldehyde & $4.12 \pm 0.76 \mathrm{a}$ & $5.22 \pm 1.48 \mathrm{a}$ & n.d. & n.d. & n.d. & 980 & 970 \\
\hline Octanal & $4.03 \pm 0.73 \mathrm{~d}$ & $2.68 \pm 0.09 \mathrm{~cd}$ & $2.06 \pm 0.37 \mathrm{bc}$ & $1.16 \pm 0.82 \mathrm{ab}$ & n.d. & 1007 & 1004 \\
\hline Nonanal & $3.16 \pm 0.26 b$ & $6.82 \pm 0.35 c$ & n.d. & n.d. & n.d. & 1109 & 1099 \\
\hline Sum & $35.78 \pm 0.52$ & $34.99 \pm 0.74$ & $4.77 \pm 0.33$ & $1.16 \pm 0.82$ & $2.77 \pm 0.10$ & & \\
\hline \multicolumn{8}{|c|}{ Ketones } \\
\hline 2,3-Butanedione & $3.94 \pm 0.28 b$ & $4.31 \pm 0.30 \mathrm{~b}$ & $4.16 \pm 0.41 \mathrm{~b}$ & $5.67 \pm 0.32 c$ & $1.84 \pm 0.42 \mathrm{a}$ & 584 & 584 \\
\hline $\begin{array}{l}\text { 3-Hydroxy-2- } \\
\text { butanone }\end{array}$ & $3.68 \pm 0.17 \mathrm{~b}$ & $3.41 \pm 0.38 b$ & $3.34 \pm 0.41 b$ & $3.11 \pm 0.07 b$ & n.d. & 710 & 708 \\
\hline 2-Pentyl-furanone & $3.12 \pm 0.09 \mathrm{ab}$ & $2.76 \pm 0.05 b$ & $3.61 \pm 0.51 \mathrm{c}$ & $2.78 \pm 0.11 \mathrm{~b}$ & n.d. & 993 & 989 \\
\hline Sum & $10.74 \pm 0.20$ & $10.48 \pm 0.28$ & $11.11 \pm 0.45$ & $11.56 \pm 0.20$ & $1.84 \pm 0.42$ & & \\
\hline \multicolumn{8}{|c|}{ Esters } \\
\hline $\begin{array}{l}\text { Formic acid, methyl } \\
\text { ester }\end{array}$ & n.d. & n.d. & n.d. & n.d. & $18.78 \pm 0.39 b$ & - & - \\
\hline $\begin{array}{c}\text { Acetic acid, ethyl } \\
\text { ester }\end{array}$ & n.d. & $2.04 \pm 1.04 \mathrm{~b}$ & $0.43 \pm 0.30 \mathrm{a}$ & n.d. & n.d. & 610 & 614 \\
\hline $\begin{array}{c}\text { Butanoic acid, methyl } \\
\text { ester }\end{array}$ & $3.39 \pm 0.52 \mathrm{ab}$ & $2.84 \pm 0.36 b$ & $4.13 \pm 0.70 \mathrm{c}$ & $2.70 \pm 0.10 \mathrm{~b}$ & $1.41 \pm 0.08 \mathrm{a}$ & 721 & 735 \\
\hline Sum & $3.39 \pm 0.52$ & $4.88 \pm 0.78$ & $4.56 \pm 0.34$ & $2.70 \pm 0.10$ & $20.19 \pm 0.28$ & & \\
\hline
\end{tabular}


Table 3. Cont.

\begin{tabular}{|c|c|c|c|c|c|c|c|}
\hline Compounds & Day 0 & Day 2 & Day 4 & Day 6 & Day 8 & KIEx & KILt \\
\hline \multicolumn{8}{|c|}{ Hydrocarbons } \\
\hline Hexane & $4.04 \pm 0.07 \mathrm{a}$ & $3.78 \pm 0.24 \mathrm{a}$ & $3.92 \pm 0.32 \mathrm{a}$ & $6.12 \pm 0.12 c$ & $5.54 \pm 0.11 b$ & 594 & 600 \\
\hline Heptane & $6.72 \pm 0.52 c$ & $5.12 \pm 0.06 \mathrm{ab}$ & $4.79 \pm 0.11 \mathrm{a}$ & $5.83 \pm 0.28 b$ & $4.52 \pm 0.27 \mathrm{a}$ & 698 & 700 \\
\hline Octane & n.d. & n.d. & $0.78 \pm 0.03 b$ & $1.01 \pm 0.07 \mathrm{c}$ & $1.67 \pm 0.00 \mathrm{~d}$ & 801 & 800 \\
\hline Nonane & $2.94 \pm 0.30 \mathrm{c}$ & $1.94 \pm 0.20 \mathrm{~b}$ & $1.42 \pm 0.19 b$ & $1.34 \pm 0.12 \mathrm{ab}$ & $0.77 \pm 0.27 \mathrm{a}$ & 901 & 900 \\
\hline Decane & $5.12 \pm 0.30 b$ & $3.56 \pm 0.18 \mathrm{a}$ & $4.77 \pm 0.40 \mathrm{~b}$ & $3.39 \pm 0.08 \mathrm{a}$ & $6.14 \pm 0.04 c$ & 1001 & 1000 \\
\hline Dodecane & $6.16 \pm 0.61 b$ & $12.22 \pm 0.77 c$ & $11.19 \pm 0.99 c$ & $6.43 \pm 0.45 b$ & $2.82 \pm 0.09 \mathrm{a}$ & 1202 & 1200 \\
\hline Tetradecane & $1.92 \pm 0.02 \mathrm{a}$ & $14.73 \pm 2.60 \mathrm{c}$ & $20.4 \pm 1.03 \mathrm{~d}$ & $15.31 \pm 1.21 \mathrm{c}$ & $7.17 \pm 1.80 \mathrm{~b}$ & 1403 & 1400 \\
\hline dl-Limonene & $3.29 \pm 0.15 b$ & $2.93 \pm 0.53 b$ & $2.18 \pm 0.01 \mathrm{a}$ & $4.68 \pm 0.04 c$ & $2.12 \pm 0.07 \mathrm{a}$ & 1043 & 1039 \\
\hline Caryophyllene & n.d. & n.d. & n.d. & n.d. & $5.49 \pm 1.04 \mathrm{~b}$ & 1459 & 1440 \\
\hline gamma-Terpinene & n.d. & n.d. & n.d. & n.d. & $3.08 \pm 0.78 b$ & 1070 & 1062 \\
\hline Sum & $30.19 \pm 0.34$ & $44.28 \pm 1.05$ & $49.45 \pm 0.54$ & $44.11 \pm 0.47$ & $39.32 \pm 0.71$ & & \\
\hline \multicolumn{8}{|c|}{ Aromatic compounds } \\
\hline 2-Pentyl-furan & $7.70 \pm 0.61 c$ & $4.28 \pm 0.20 \mathrm{~b}$ & $3.66 \pm 0.53 b$ & n.d. & n.d. & 994 & 992 \\
\hline p-Cymene & $4.01 \pm 0.09 \mathrm{ab}$ & $10.29 \pm 6.28 b$ & $3.18 \pm 0.29 \mathrm{ab}$ & $2.65 \pm 0.29 \mathrm{a}$ & $3.20 \pm 0.31 \mathrm{ab}$ & 1037 & 1026 \\
\hline Sum & $11.71 \pm 0.44$ & $14.56 \pm 4.44$ & $6.84 \pm 0.43$ & $2.65 \pm 0.29$ & $3.20 \pm 0.31$ & & \\
\hline \multicolumn{8}{|c|}{ Sulfur compounds } \\
\hline Dimethyl-disulfide & n.d. & n.d. & $2.70 \pm 0.09 c$ & $1.34 \pm 0.04 \mathrm{~b}$ & n.d. & 751 & 746 \\
\hline
\end{tabular}

n.d. $=$ not detected. The values are the means of 6 measurements, $(n=6) \pm$ S.D., a.b.c Means with different letters in the same row are statistically different $(p<0.05)$, KIEx = Kovac Index experimentally determined data, KILi = Kovac Index literature data, Nist 05, J. Wiley \& Sons Ltd., West Sussex, England.

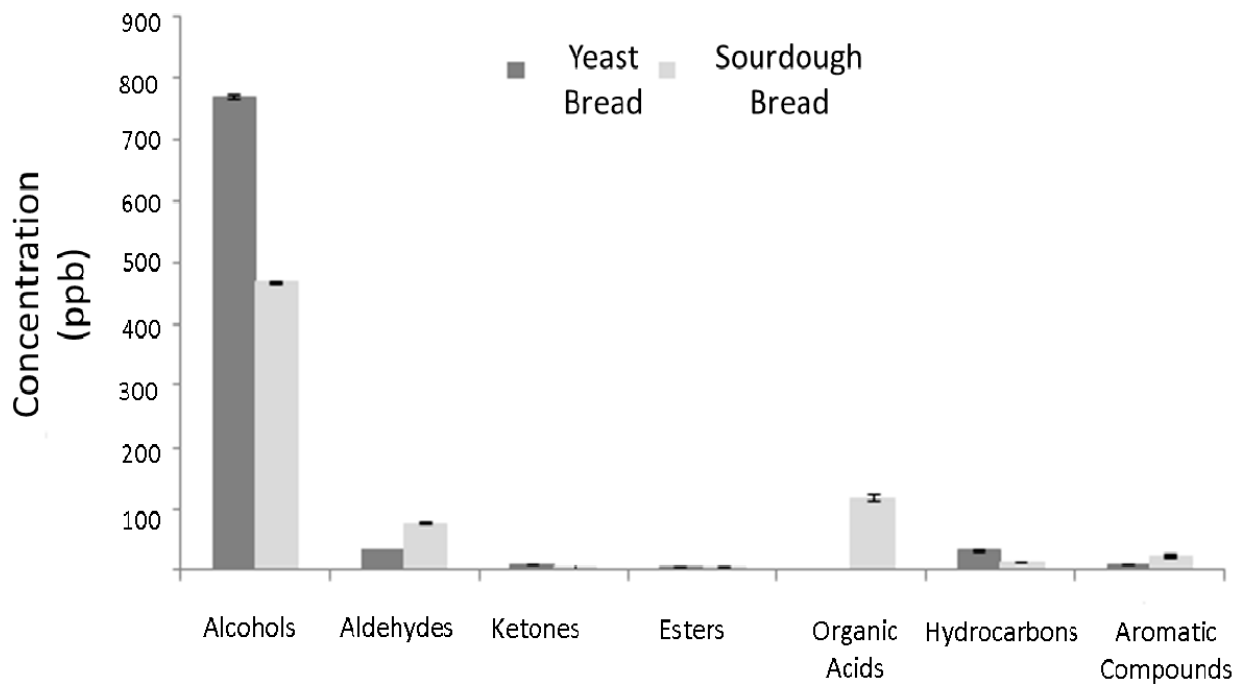

Figure 5. Bar diagram showing differences in volatile compounds between yeast bread and sourdough bread on day of bread preparation.

Alcohols identified included ethanol (alcoholic odor), 1-propanol (buttery odor), 2methyl-1-propanol (ethereal odor), 3-methyl-1-butanol (malty odor), 2-methyl-1-butanol (fragrant odor), 1-hexanol (grass/sweet/woody odor), 1-octen-3-ol (acidic odor), and pentanol (fruity, sweet odor). The total alcohol concentration was higher $(p<0.05)$ in yeast bread compared to sourdough bread (Figure 5). Ethanol is the main product of yeast fermentation. Minor products of yeast fermentation include butanol and propanol derivatives [52]. Short-chain alcohols are produced through sugar fermentation, while longchain alcohols are produced through amino acid metabolism [53]. Of the 33 sourdough LAB isolates studied in detail by De Vuyst et al. [40], all heterofermentative LAB strains produced ethanol, lactic acid, and acetic acid in agreement with the results of the present study. L. sanfranciscensis (see below) and L. plantarum produce a wide range of volatile 
compounds [51]. In addition to ethanol, lactic acid, and acetic acid, heterofermentative LAB also produce ethyl acetate with some alcohols and aldehydes.

Ketones and aldehydes identified in the present study include 3-hydroxy-2-butanone (buttery odor), 2,3-butanedione (intense buttery odor), 2-pentylfuranone (green/fruity odor), (hexanal (green/grass odor), 3-methyl-butanal and 2-methyl-butanal (malty odor), heptanal (green/fatty odor), benzaldehyde (bitter almond odor), octanal (fruity/soapy odor), nonanal (sweet/mellon odor), and furfural (roasted odor). Carbonyl compounds are mostly the products of hydroperoxide decomposition; i.e., hexanal and pentanal form through the decomposition of linoleic acid. The Maillard reaction also produces numerous aldehydes and ketones, i.e., 3-methyl-butanal being a product of the Maillard reaction [54] and ethanol, 2-methyl-1-propanol, 2-methyl-1-butanol, 3-methyl-1-butanol, and benzaldehyde being products of yeast fermentation [55]. LAB also liberate aroma precursors such as amino acids, which are degraded into aldehydes or the corresponding alcohols [55]. As shown in Figure 2, aldehyde concentration was higher $(p<0.05)$ in sourdough bread compared to yeast bread. The trend was reverse regarding ketones.

Esters identified included methyl formate (ethereal odor), ethyl acetate (sweet odor), and methyl butyrate (apple-pineapple fruity odor). Ester production is mainly due to heterofermentative LAB metabolism [56]. Ester concentration was higher $(p<0.05)$ in yeast leavened compared to sourdough bread. Of the organic acids, acetic acid (pungent/sour odor) was identified only in sourdough bread at high concentrations. Acetic acid is the product of lactic acid fermentation. Heterofermentative LAB produce $50-65 \%$ lactic acid but also acetic acid, ethanol, and $\mathrm{CO}_{2}$ [57]. Of the hydrocarbons, hexane and other alkanes (alkane-like odor) were identified. 2-pentylfuran (fruity odor), and dimethyl-disulfide are products of LAB fermentation [56]. p-Cymene (mild pleasant odor) has been also identified by Seitz et al. [58] in sourdough bread. Hydrocarbon concentration was higher $(p<0.05)$ in the yeast leavened bread compared to the sourdough bread. Lastly, aromatic compounds were higher $(p<0.05)$ in sourdough compared to yeast leavened bread.

According to De Vuyst et al. [40,59], spontaneous sourdoughs are generally specific to a region because wild $\mathrm{LAB}$ and yeast species prevail depend on local ecological factors. Temperature, time, and the number of backsloppings influence the yeast and LAB fermentations and lipid oxidation and hence the volatile profile of sourdough [3]. Present results regarding the flavor profile of yeast leavened bread are in good agreement with those of Latou et al. [26], Bianchi et al. [27], and Cho and Peterson [60], while those of the sourdough bread are in good agreement with those of Petel et al. [3] and Plessas et al. [61]. In addition to the above volatile compounds, one would expect the presence of pyrazines [62], as bread involves baking. However, such compounds, were not identified in the present study. This may be attributed to the fact that pyrazines rapidly evaporate from the sample due to their high volatility.

A decrease in ethanol concentration after 5 days of storage of sourdough bread was also reported by Plessas et al. [61], which is in agreement with the present study. As a general rule, the deterioration of bread aroma may be the result of the loss of several volatiles during the bread ageing process as well as the formation of "off-flavors" occurring via the oxidation of bread lipids during storage. The above authors showed a dramatic decrease of the number and the amount of volatile compounds after five days of storage, which is something that is also observed in the present study. Soukoulis et al. [63] studied the volatile profile of bread prepared with the addition of lactic acid bacteria using Solid Phase Micro Extraction- Gas Chromatography /Mass Spectrometry (SPME-GC/MS) and identified most of the compounds present in sourdough bread found in the present study. Lastly, Xu et al. [64] used a mixture of starter cultures of yeast and lactobacilli (L. sanfranciscensis and L. sakei) and yeasts (Kazachstania humilis, Saccharomyces cerevisiae, and Wickerhamomyces anomalus) starter cultures to prepare sourdough wheat bread and studied the flavor volatiles produced. The volatile profile recorded was similar to that of the present study with the exception of a more complex ester profile compared to the present study. 


\subsubsection{Mechanical Parameters (Texture Profile Analysis-TPA)}

Of the mechanical properties determined using texture profile analysis (hardness, springiness, cohesiveness, gumminess, and chewiness), the present study focused on hardness and springiness (shown in Table $4 \mathrm{a}, \mathrm{b}$ ). Initial values of hardness were $4.06 \pm 0.59 \mathrm{~N}$ for yeast bread and $7.15 \pm 1.94 \mathrm{~N}$ for sourdough bread. Hardness increased with storage time $(p<0.05)$ in both breads. At the time of sensory rejection (day $4-5$ for yeast bread and day 10 for sourdough bread), hardness reached $11.88 \pm 3.42 \mathrm{~N}$ for yeast bread and $35.40 \pm 5.89 \mathrm{~N}$ $(p<0.05)$ for sourdough bread. It is apparent that sourdough bread is harder in texture compared to yeast leavened bread. This finding is in agreement with Sanz-Penella et al. [45], who showed that sourdough bread hardness increases with amount of sourdough added to wheat flour. Likewise, Latou et al. [26] working with preservative-added wheat bread reported an initial (day 0) hardness value of $4.8 \mathrm{~N}$, reaching $15.7 \mathrm{~N}$ on day 9 of storage for control bread.

Table 4. The effect of storage time on (a) hardness and (b) springiness development of yeast and sourdough bread stored at $25^{\circ} \mathrm{C}$.

\begin{tabular}{cccccccc}
\hline & \multicolumn{3}{c}{ a. Hardness } & \multicolumn{3}{c}{ b. Springiness } \\
\hline \multicolumn{2}{c}{ Yeast Bread } & \multicolumn{2}{c}{ Sourdough Bread } & \multicolumn{2}{c}{ Yeast Bread } & \multicolumn{2}{c}{ Sourdough Bread } \\
\hline Day & $\mathbf{( N )}$ & Day & $\mathbf{( N )}$ & Day & $\mathbf{( m m )}$ & Day & $(\mathbf{m m})$ \\
\hline 0 & $4.06 \pm 0.59 \mathrm{a}$ & 0 & $7.15 \pm 1.94 \mathrm{a}$ & 0 & $3.76 \pm 0.92 \mathrm{a}$ & 0 & $1.74 \pm 0.39 \mathrm{a}$ \\
2 & $4.76 \pm 2.58 \mathrm{ab}$ & 2 & $18.37 \pm 1.88 \mathrm{ab}$ & 2 & $4.53 \pm 0.85 \mathrm{a}$ & 2 & $1.91 \pm 0.60 \mathrm{a}$ \\
4 & $11.78 \pm 3.53 \mathrm{bc}$ & 4 & $26.21 \pm 6.84 \mathrm{abc}$ & 4 & $5.07 \pm 0.70 \mathrm{a}$ & 4 & $2.00 \pm 0.15 \mathrm{ab}$ \\
6 & $11.88 \pm 3.42 \mathrm{bc}$ & 6 & $49.34 \pm 11.42 \mathrm{~cd}$ & 6 & $3.42 \pm 0.62 \mathrm{a}$ & 6 & $2.07 \pm 0.12 \mathrm{ab}$ \\
8 & $12.52 \pm 3.02 \mathrm{c}$ & 8 & $39.43 \pm 7.67 \mathrm{bcd}$ & 8 & $4.72 \pm 0.51 \mathrm{a}$ & 8 & $2.61 \pm 0.41 \mathrm{ab}$ \\
& & 10 & $35.40 \pm 5.89 \mathrm{bcd}$ & & & 10 & $3.28 \pm 0.30 \mathrm{~b}$ \\
& & 12 & $53.78 \pm 10.07 \mathrm{~d}$ & & & 12 & $2.51 \pm 0.49 \mathrm{ab}$ \\
& & 14 & $52.65 \pm 10.68 \mathrm{~cd}$ & & & 14 & $2.93 \pm 0.36 \mathrm{ab}$ \\
& & 16 & $58.60 \pm 10.83 \mathrm{~d}$ & & & 16 & $2.76 \pm 0.35 \mathrm{ab}$ \\
& & 18 & $48.09 \pm 16.20 \mathrm{~cd}$ & & & 18 & $2.21 \pm 0.61 \mathrm{ab}$ \\
\hline
\end{tabular}

a, b, c, d Means with different letters in the same column are statistically different (Tukey's test, $p<0.05$ ).

Springiness is a measure of bread samples to return to their initial condition upon compression. Initial values of springiness were $3.76 \pm 0.92 \mathrm{~N}$ for yeast bread and $1.74 \pm 0.39 \mathrm{~N}$ $(p<0.05)$ for sourdough bread. Springiness varied with storage time $(p<0.05)$ only for the sourdough bread. At the time of sensory rejection (days 5-6 for yeast bread and day 10 for sourdough bread), springiness reached $5.07 \pm 0.70 \mathrm{~N}$ for yeast bread and $3.28 \pm 0.30 \mathrm{~N}$ for sourdough bread.

It is clear that yeast bread is more elastic in texture compared to sourdough bread. These findings are in general agreement with those of Rinaldi et al. [65], who applied TPA to both yeast leavened and sourdough bread stored for 5 days. They reported that the sourdough bread was harder than the yeast bread and that the hardness increased in both breads with time. Cohesiveness was higher in the yeast bread in contrast to the results of the present study showing a higher cohesiveness for sourdough bread (results not shown). Casado et al. [66] ran TPA analysis in yeast and sourdough bread and reported a higher hardness and chewiness in sourdough bread. Springiness did not show statistically significant differences between the two breads. Finally, in contrast to the results of the present study, Hadaegh et al. [67] reported a lower hardness in toast wheat bread with the addition of sourdough compared to yeast leavened bread.

\subsection{Sensory Analysis}

Of the sensory attributes monitored (appearance, aroma, taste, and texture), aroma and taste showed a decreasing acceptability trend with time and proved equally sensitive sensory attributes for the quality evaluation of bread (Figure 6). Based on aroma and taste, yeast bread was rejected after 5-6 days, while sourdough bread was rejected after 10 days of storage. Similar results were recorded for texture. Finally, based on appearance, 
yeast bread was rejected after ca. $4-5$ days, while sourdough bread was rejected after 16 days due to mold growth. The most sensitive sensory attribute for yeast leavened bread proved to be appearance (mold growth, day 5) as well as texture hardening (days 5-6), while for sourdough bread, the most sensitive sensory attribute was texture hardening (day 10). There was a partial agreement between sensory and microbiological data. Based on TVC, the shelf life of yeast leavened bread was $4-5$ days (limit $10^{6} \mathrm{cfu} / \mathrm{g}$ ) and 18+ days for sourdough bread stored at $25{ }^{\circ} \mathrm{C}$. The same holds for the pathogen $B$. cereus. Mold growth limited the microbiological shelf life to day 5 for YLB and 16 days fir SDB. Finally, Enterobacteriaceae recorded very low counts (lower than $1 \log \mathrm{cfu} / \mathrm{g}$ ) for all treatments and did not critically affect product shelf life.

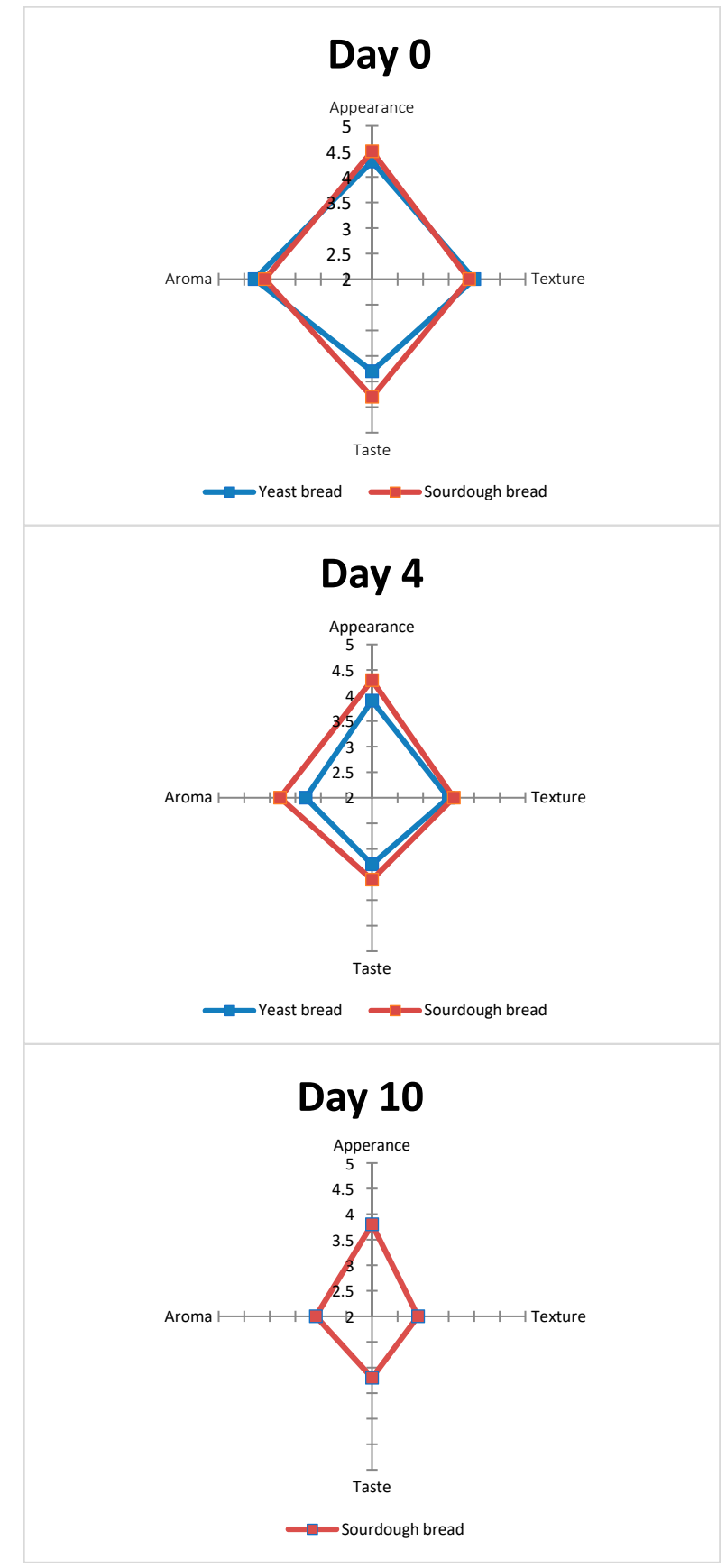

Figure 6. Sensory evaluation of yeast and sourdough breads in the form of star diagrams at different storage times. 
The sensory data of the present study are in good agreement with those in the literature. Mohsen et al. [4] conducted sensory evaluation on breads prepared with the addition of different amounts of LAB. They reported that the breads prepared with LAB received higher scores regarding texture, aroma, and taste compared to control breads. Edeghor et al. [68] prepared yeast leavened bread, bread containing LAB, and bread containing both cultures. The bread prepared with the addition of LAB received the highest scores regarding aroma and taste followed by the bread prepared with the mixed culture. Regarding appearance and texture, the bread with the mixed culture received the highest scores followed by the yeast leavened bread. Similar results were reported by Quintero Lira et al. [69], who compared bread prepared using baker's yeast plus Lb. paracasei to that prepared using only baker's yeast. Bread prepared with the mixed culture consistently received higher scores regarding appearance, texture, taste, and aroma. Marcus et al. [46] prepared (i) conventional bread, (ii) sourdough bread using the antifungal strain Lactobacillus amylovorus, and (iii) bread containing $0.5 \%$ calcium propionate (CA) commonly used in bread as an antifungal agent. For a salt content of $0.6 \%$, they reported a shelf life of 2-3 days for control bread, 13-14 days for sourdough bread, and 12 days for bread containing (CA). Finally, the results of the present study are also in good agreement with those of Casado et al. [66] and Hadaegh et al. [67], who reported that the sensory panels preferred the sourdough bread samples to those of the yeast leaved bread.

\section{Conclusions}

In the present study, 16S analysis showed that the bacterial profile of sourdough was dominated by a single genus, (Lactobacillus), whereas the eukaryotic load showed that at the genus level, Saccharomyces and Alternaria were the most abundant genera, independently of the gene sequenced (18S or ITS). A. hordeicola and M. tassiana were reported for the first time in the eukaryotic load of traditional sourdoughs. The use of sourdough in bread making resulted in a product that was harder and less elastic in texture, richer in aroma (higher concentration of organic acids, aromatic compounds, and aldehydes), and had a desirable light sour taste with a considerably longer shelf life compared to conventional yeast leavened bread. Based primarily on microbiological (mold growth), and sensory (texture) data, the shelf life of conventional yeast leavened bread was ca. 4-5 days and 10 days for artisanal sourdough bread stored at $25^{\circ} \mathrm{C}$. Depending on the specific microbiota associations in sourdough, type of flour used, and storage temperature of SDB, its quality characteristics and shelf life will vary. Most of the information in the literature on SDB stored at room temperature refers to a shelf life between 4 and 7 days. We have shown that using the specific sourdough, the shelf life of SDB is extended to 10 days even at slightly elevated ambient temperatures $\left(25^{\circ} \mathrm{C}\right)$. This finding along with the specific associations of $\mathrm{LAB}$ and yeasts in the artisanal sourdough used comprise the novelty of the present study.

Author Contributions: Conceptualization, M.G.K.; methodology, M.G.K.; A.V.B.; S.M.; A.A.; software, I.S.K.; S.M.; A.A.; formal analysis, P.K.; I.S.K.; S.M.; A.A.; resources, M.G.K.; A.V.B.; I.S.K.; S.M.; A.A.; data curation, P.K.; I.S.K.; M.G.K.; A.V.B.; S.M.; A.A.; writing—original draft preparation, P.K.; M.G.K.; S.M.; A.A.; writing-review and editing, A.V.B.; M.G.K.; I.S.K.; S.M.; A.A.; supervision, A.V.B.; M.G.K.; project administration, A.V.B.; M.G.K. All authors have read and agreed to the published version of the manuscript.

Funding: This research received no external funding.

Institutional Review Board Statement: Not applicable.

Informed Consent Statement: Not applicable.

Data Availability Statement: Not applicable.

Acknowledgments: The authors would like to thank Giorgos Tsobanidis of Saint George Flour Mills, in Ioannina for donating the flour samples used in this study.

Conflicts of Interest: The authors declare no conflict of interest. 


\section{References}

1. Nagodawithana, T.W.; Trivedi, N. Yeast Selection for Baking. In Yeast Strain Selection; Panchal, C.J., Ed.; Marcel Decker: New York, NY, USA, 1990; pp. 139-184.

2. Ganzle, M.; Gobbetti, M. Handbook of Sourdough Biotechnology; Springer US: Boston, MA, USA, 2013.

3. Petel, C.; Onno, B.; Prost, C. Sourdough volatile compounds and their contribution to bread. Trends Food Sci. Technol. 2017, 59, 105-123. [CrossRef]

4. Mohsen, S.M.; Aly, M.H.; Attia, A.A.; Osman, D.B. Effect of Sourdough on Shelf Life, Freshness and Sensory Characteristics of Egyptian Balady Bread. J. Appl. Environ. Microbiol. 2016, 4, 39-45.

5. Hansen, A. Sourdough Bread. In Handbook of Food Science, Technology and Engineering; Hui, Y.H., Sherka, F., Eds.; Taylor and Francis Group, LLC: Boca Raton, FL, USA, 2006; p. 183.

6. Salovaara, H. Lactic Acid Bacteria in Cereal-Based Products. In Lactic Acid Bacteria. Microbiological and Functional Aspects; Salminen, S., von Wright, A., Ouwehand, A., Eds.; Marcel Dekker: New York, NY, USA, 2004; pp. 431-451.

7. Minervini, F.; Di Cagno, R.; Lattanzi, A.; De Angelis, M.; Antonielli, L.; Cardinali, G.; Cappelle, S.; Gobbetti, M. Lactic acid bacterium and yeast microbiotas of 19 sourdoughs used for traditional/typical Italian breads: Interactions between ingredients and microbial species diversity. Appl. Environ. Microbiol. 2012, 78, 1251-1264. [CrossRef]

8. De Vuyst, L.; Van Kerrebroeck, S.; Harth, H.; Huys, G.; Daniel, H.M.; Weckx, S. Microbial ecology of sourdough fermentations: Diverse or uniform? Food Microbiol. 2014, 37, 11-29. [CrossRef]

9. Legan, J.D. Mould spoilage of bread: The problem and some solutions. Int. Biodeterior. Biodegrad. 1993, 32, 33-53. [CrossRef]

10. Novotini, D.; Špoljarić, I.V.; Drakula, S.; Čukelj, N.; Voučko, B.; Ščetar, M.; Galić, K.; Ćurić, D. Influence of Barley Sourdough and Vacuum Cooling on Shelf Life Quality of Partially Baked Bread. Food Technol. Biotechnol. 2017, 55, 464-474. [CrossRef] [PubMed]

11. Legan, J.D.; Voyseyt, P.A. Yeast spoilage of bakery products and ingredients. J. Appl. Bacteriol. 1991, 70, 361-371. [CrossRef] [PubMed]

12. Arendt, E.K.; Ryan, L.A.M.; Bello, F.D. Impact of sourdough on the texture of bread. Food Microbiol. 2007, 24, 165-174. [CrossRef]

13. Katina, K. Sourdough: A Tool for the Improved Flavor, Texture and Shelf Life of Wheat Bread; Vtt Technical Research Center of Finland: Helsinki, Finland, 2005.

14. Katina, K.; Salmenkallio-Marttila, M.; Partanen, R.; Forssell, P.; Autio, K. Effects of sourdough and enzymes on staling of highfibre wheat bread. LWT Food Sci. Technol. 2006, 39, 479-491. [CrossRef]

15. European Council. EU Regulation 1924/2006 of the European Parliament and of the Council of 20 December 2006 on Nutrition and Health Claims Made on Foods; European Council: Brussels, Belgium, 2006; pp. 9-25.

16. APHA. Compendium of Methods for the Microbiological Examination of Foods, 4th ed.; APHA: Washington, DC, USA, $2001 ;$ p. 676.

17. Klindworth, A.; Pruesse, E.; Schweer, T.; Peplies, J.; Quast, C.; Horn, M.; Glöckner, F. Evaluation of general 16S ribosomal RNA gene PCR primers for classical and next-generation sequencing-based diversity studies. Nucleic Acids Res. 2013, 41, e1. [CrossRef]

18. Chemidlin Prévost-Bouré, N.; Christen, R.; Dequiedt, S.; Mougel, C.; Lelièvre, M.; Jolivet, C.; Shahbazkia, H.R.; Guillou, L.; Arrouays, D.; Ranjard, L. Validation and application of a PCR primer set to quantify fungal communities in the soil environment by real-time quantitative PCR. PLoS ONE 2011, 6, e24166.

19. Bokulich, N.A.; Mills, D.A. Improved selection of internal transcribed spacer-specific primers enables quantitative, ultra-highthroughput profiling of fungal communities. Appl. Environ. Microbiol. 2013, 79, 2519-2526. [CrossRef] [PubMed]

20. Bolyen, E.; Rideout, J.R.; Dillon, M.R.; Bokulich, N.A.; Abnet, C.C.; Al-Ghalith, G.A.; Alexander, H.; Alm, E.J.; Arumugam, M.; Asnicar, F.; et al. Reproducible, interactive, scalable and extensible microbiome data science using QIIME 2. Nat. Biotechnol. 2019, 37, 852-857. [CrossRef]

21. Martin, M. Cutadapt removes adapter sequences from high-throughput sequencing reads. EMBnet. J. 2011, 17, 10-12. [CrossRef]

22. Callahan, B.J.; McMurdie, P.J.; Rosen, M.J.; Han, A.W.; Johnson, A.J.A.; Holmes, S.P. Dada2: High-resolution sample inference from illumina amplicon data. Nat. Methods 2016, 13, 581. [CrossRef] [PubMed]

23. R Development Core Team. R: A Language and Environment for Statistical Computing. R Foundation for Statistical Computing; R Core Team: Vienna, Austria, 2010.

24. McMurdie, P.J.; Holmes, S. Phyloseq: A bioconductor package for handling and analysis of high-throughput phylogenetic sequence data. Pac. Symp. Biocomput. 2012, 17, 235-246.

25. Wickham, H. ggplot2: Elegant Graphics for Data Analysis; Springer: New York, NY, USA, 2009.

26. Latou, E.; Mexis, S.F.; Badeka, A.V.; Kontominas, M.G. Shelf life extension of sliced wheat bread using either an ethanol emitter or an ethanol emitter combined with an oxygen absorber as alternatives to chemical preservatives. J. Cereal Sci. 2010, 52, $457-465$. [CrossRef]

27. Bianchi, F.; Careri, M.; Chiacaro, E.; Musci, M.; Vittadini, E. Gas chromatographic-mass spectrometric characterization of the Italian protected designation of origin 'Altamura' bread volatile profile. Food Chem. 2008, 110, 787-793. [CrossRef]

28. International Commission on Microbiological Specifications for Foods. Sampling for Microbiological Analysis: Principles and Scientific Applications, 2nd ed.; University of Toronto Press: Toronto, ON, Canada, 1986; Volume 2.

29. Jonkuvienè, D.; Vaičiulytè-Funk, L.; Šalomskienè, J.; Alenčikienè, G.; Mieželienè, A. Potential of Lactobacillus reuteri from Spontaneous Sourdough as a Starter Additive for Improving Quality Parameters of Bread. Food Technol. Biotechnol. 2016, 54, 342-350. [CrossRef] [PubMed] 
30. Fernandez, U.; Vodovotz, Y.; Courtney, P.; Pascall, M. Extended shelf life of soy bread using modified atmosphere packaging. J. Food Protect. 2006, 69, 693-698. [CrossRef]

31. Tatar, O.M.; Rehman, S.; Mueen-Ud-Din, G.; Murtaza, M.A. Studies on the shelf life of bread using acidulants and their salts. Turk. J. Biol. 2010, 34, 133-138.

32. Samapundo, S.; Deschuyfteleer, N.; Van Laere, D. Effect of $\mathrm{NaCl}$ reduction and replacement on the growth of fungi important to the spoilage of bread. J. Food Microbiol. 2010, 27, 749-756. [CrossRef]

33. Jay, J.M.; Loessner, M.J.; Golden, D.A. Modern Food Microbiology, 7th ed.; Springer: New York, NY, USA, 2005.

34. EFSA. Bacillus cereus and other Bacillus spp in foodstuffs. J. EFSA 2005, 175, 1-8.

35. Bailey, C.P.; von Holy, A. Bacillus spore contamination associated with commercial bread manufacture. Food Microbiol. 1993, 10, 287-294. [CrossRef]

36. Ravimannan, N. Study on microbial profile of bread during storage. Int. J. Adv. Res. Biol. Sci. 2016, 3, 60-63.

37. Hutkins, R.W.; Nannen, N.L. pH Homeostasis in Lactic Acid Bacteria. J. Dairy Sci. 1993, 76, 2354-2365. [CrossRef]

38. Park, J.; Seo, J.S.; Kim, S.; Shin, S.; Park, J.H.; Han, N.S. Microbial Diversity of Commercial Makgeolli and Its Influence on the Organoleptic Characteristics of Korean Rice Sourdough, Jeung-Pyun. J. Microbiol. Biotechnol. 2017, 27, 1736-1743. [CrossRef] [PubMed]

39. NSW Food Authority. Microbiological Quality Guide for Ready-to-Eat Foods. A Guide to Interpreting Microbiological Results; NSW Food Authority: Newington, NSW, Australia, 2009.

40. De Vuyst, L.; Schrijvers, V.; Paramithiotis, P.; Hoste, B.; Vancanneyt, M.; Swings, J.; Kalantzopoulos, G.; Tsakalidou, E.; Messens, W. The biodiversity of lactic acid bacteria in Greek traditional wheat sourdoughs is reflected in both composition and metabolite formation. Appl. Environ. Microbiol. 2002, 68, 6059-6069. [CrossRef] [PubMed]

41. Palla, M.; Cristani, C.; Giovannetti, M.; Agnolucci, M. Identification and characterization of lactic acid bacteria and yeasts of PDO Tuscan bread sourdough by culture dependent and independent methods. Int. J. Food Microbiol. 2017, 250, 19-26. [CrossRef] [PubMed]

42. Lhomme, E.; Lattanzi, A.; Dousset, X.; Minervini, F.; De Angelis, M.; Lacaze, G.; Onno, B.; Gobbetti, M. Lactic acid bacterium and yeast microbiotas of sixteen French traditional sourdoughs. Int. J. Food Microbiol. 2015, 215, 161-170. [CrossRef]

43. Banu, I.; Vasilean, I.; Barbu, V.; Iancu, C. The effect of some technological factors on the rye sourdough bread. Chem. Chem. Eng. Biotechnol. Food Ind. 2011, 12, 197-202.

44. Mert, I.D.; Campanella, O.H.; Sumnu, G.; Sahin, S. Gluten-Free Sourdough Bread Prepared with Chestnut and Rice Flour; Department of Food Engineering, Engineering Faculty, Middle East Technical University, Universiteler Mah: Ankara, Turkey, 2014.

45. Sanz-Penella, J.M.; Tamayo-Ramos, J.A.; Haros, C.M. Application of Bifidobacteria as starter culture in whole wheat sourdough breadmaking. Food Bioprocess. Technol. 2012, 5, 2370-2380. [CrossRef]

46. Marcus, C.E.; Mairinger, B.R.; Zannini, E.; Ryan, L.A.M.; Cashman, A.D.; Arendt, E.K. The effect of sourdough and calcium propionate on the microbial shelf-life of salt reduced bread. Appl. Microbiol. Biotechnol. 2012, 96, 493-501.

47. Chirife, J.; Favetto, G.J. Some physicochemical basis of food preservation by combined methods. Food Res. Int. 1992, 25, 389-396. [CrossRef]

48. Smith, J.P.; Daifas, D.P.; El-Khoury, W.; Koukoutsis, J.; El-Khoury, A. Shelf life and safety concerns of bakery products-A review. Crit. Rev. Food Sci. Nutr. 2004, 44, 19-55. [CrossRef] [PubMed]

49. Birch, A.N.; Peterson, M.A.; Hansen, A.S. Aroma of wheat bread crumb. Cereal Chem. 2014, 91, 105-114. [CrossRef]

50. Hazelwood, L.A.; Daran, J.M.; van Maris, A.J.A.; Pronk, J.T.; Dickinson, J.R. The Ehrlich pathway for fusel alcohol production: A century of research on Saccharomyces cerevisiae metabolism. Appl. Environ. Microbiol. 2014, 74, 2259-2266. [CrossRef] [PubMed]

51. Hansen, A.; Hansen, B. Flavour of Sourdough wheat bread crumb. Z. Lebensm. Unters. Forsch. 1996, 202, 244-249. [CrossRef]

52. Drapron, R.; Richard-Molard, D. Influence de Divers Procedes Technologiques sur la Formations de l' Arộme du Pain. Repercussions sur sa Qualité. In Le Pain; Buré, J., Ed.; Actes du Researche Scientifique: Paris, France, 1979; pp. $143-161$.

53. Maga, J.A. Bread Flavor. Crit. Rev. Food Technol. 1974, 5, 55-142. [CrossRef]

54. Pozo-Bayón, M.A.; Guichard, E.; Cayot, N. Flavor control in baked cereal products. Food Rev. Int. 2006, 22, 335-379. [CrossRef]

55. Hansen, A.; Schieberle, P. Generation of aroma compounds during sourdough fermentation: Applied and fundamental aspects. Trends Food Sci. Technol. 2005, 16, 85-94. [CrossRef]

56. Kaseleht, K.; Paalme, T.; Mihhalevski, A.; Sarand, I. Analysis of volatile compounds produced by different species of lactobacilli in rye sourdough using multiple headspace extraction. Int. J. Food Sci. Technol. 2011, 46, 1940-1946. [CrossRef]

57. Spicher, G.; Stephan, H. Handbuch Sauerteig: Biologie, Biochemie, Technologie; B.B.V. Wirstchaft Informationen GmbH: Hamburg, Germany, 1987.

58. Seitz, L.M.; Chung, O.I.; Rengarajan, R. Volatiles in selected commercial breads. Cereal Chem. 1998, 75, 847-853. [CrossRef]

59. De Vuyst, L.; Neysens, P. The sourdough microflora: Biodiversity and metabolic interactions. Trends Food Sci. Technol. 2005, 16, 43-56. [CrossRef]

60. Cho, H.; Peterson, D.G. Chemistry of bread aroma. Food Sci. Biotechnol. 2010, 19, 575-582. [CrossRef]

61. Plessas, S.; Bekatorou, A.; Gallanagh, J.; Nigam, P.; Koutinas, A.A.; Psarianos, C. Evolution of aroma volatiles during storage of sourdough breads made by mixed cultures of Kluyveromyces marxianus and Lactobacillus delbrueckii ssp. bulgaricus or Lactobacillus helveticus. Food Chem. 2008, 107, 883-889. 
62. Maga, J.A. Pyrazine update. Food Rev. Intl. 1992, 8, 479-558. [CrossRef]

63. Soukoulis, C.; Yonekura, L.; Gan, H.H.; Behboudi-Jobbehdar, S.; Parmenter, C.D.J.; Fisk, I.D. Probiotic edible films as a new strategy for developing functional bakery products: The case of pan bread. Food Hydrocoll. 2014, 39, 231-242. [CrossRef] [PubMed]

64. Xu, D.; Zhang, Y.; Tang, K.; Hu, Y.; Xu, X.; Gänzle, M.G. Effect of Mixed Cultures of Yeast and Lactobacilli on the Quality of Wheat Sourdough Bread. Front. Microbiol. 2019, 10, 2113. [CrossRef]

65. Rinaldi, M.; Paciulli, M.; Caligiani, A.; Scazzina, F.; Chiavaro, E. Sourdough fermentation and chestnut flour in gluten-free bread: A shelf life evaluation. Food Chem. 2016, 224, 144-152. [CrossRef] [PubMed]

66. Casado, A.; Álvarez, A.; Gonzalez, L.; Fernandez, D.; Marcos, J.L.; Tornadijo, M.E. Effect of Fermentation on Microbiological, Physicochemical and Physical Characteristics of Sourdough and Impact of its Use on Bread Quality. Czech J. Food Sci. 2017, 35, 496-506.

67. Hadaegh, H.; Seyyedain Ardabili, S.M.; Tajabadi Ebrahimi, M.; Chamani, M.; Azizi Nezhad, R. The Impact of Different Lactic Acid Bacteria Sourdoughs on the Quality Characteristics of Toast Bread. J. Food Qual. 2017, 1, 1-11. [CrossRef]

68. Edeghor, U.; Lennox, J.; Etta-Abgo, B.; Aminadokiari, D. Bread fermentation using synergistic activity between lactic acid bacteria (Lactobacillus bulgaricus) and baker's yeast (Sacchromyces cerevisae). Pak. J. Food Sci. 2016, 26, 46-53.

69. Quintero Lira, A.; Alvarado-Resendiz, M.G.; Soto Simental, S.; Piloni Martini, J.; Reyes-Santamaria, M.I.; Guemes-Vera, N. Use of Lactobacillus from Pulque in Sourdough. Adv. Microbiol. 2014, 4, 969-977. [CrossRef] 